SINAI Journal of Applied Sciences 10 (2) $2021 \quad 067-088$

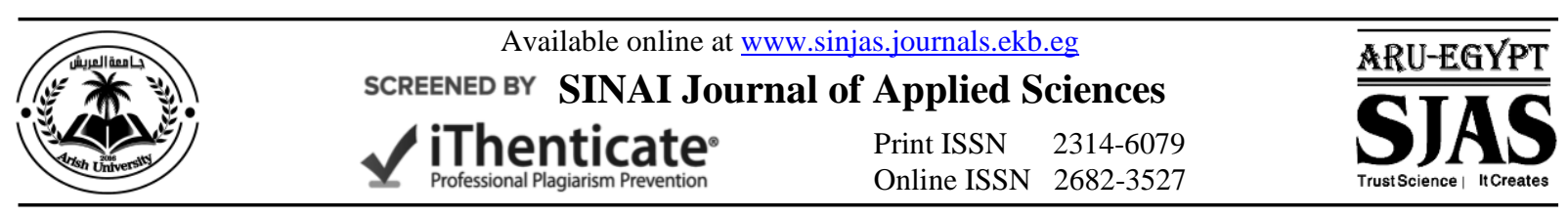

\title{
RESPONSE OF WATER STRESSED TOMATO PLANTS TO SOIL ORGANIC AMENDMENTS
}

\author{
Mahmoud I. Mahmoud $^{1 *}$, S.A.A. AbuoEl-Kasem ${ }^{2}$ and M.S.A. El-Kassas ${ }^{3}$ \\ 1. Dept. Plant Prod. (Veg. Branch), Fac. Environ. Agric. Sci., Arish Univ., Egypt. \\ 2. Dept. Self-Pollinated Veg. Res., Inst. Hort. Res., Cent. Agric. Res., Giza, Egypt \\ 3. Dept. Water and Soil, Fac. Environ. Agric. Sci., Arish Univ., Egypt
}

\begin{tabular}{l} 
ARTICLE INFO \\
\hline Article history: \\
Received: $16 / 09 / 2021$ \\
Revised: $20 / 09 / 2021$ \\
Accepted: $11 / 10 / 2021$ \\
Available online: $11 / 10 / 2021$ \\
\hline Keywords: \\
Tomato, \\
Biochar, \\
Barley straw, \\
Drought stress
\end{tabular}

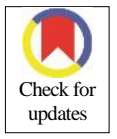

\begin{abstract}
Two field trials were conducted during successive two summer seasons of 2019 and 2020 at the experimental farm, Fac. Environ. Agric. Sci., Arish Univ., North Sinai, Egypt to investigate the influence of drought stress (100\% of crop evapotranspiration "ETc" (full irrigation " $\mathrm{D}_{0}$ "), 85\% ETc (low drought stress " $\left.\mathrm{D}_{\mathrm{L}} "\right)$, 75\% ETc (medium drought stress " $\mathrm{D}_{\mathrm{M}}$ ") and 55\% ETc (high drought stress " $\mathrm{D}_{\mathrm{H}}$ ") and organic amendments (biochar "BCH" and barley straw "ST") on soil water relation as well as growth, yield and quality of tomato. Biochar+barley straw treatment exhibited the highest increment under all water levels of the three water relation, i.e., field capacity (FC), plant permanent wilting point (PWP) and plant available water content (AWC) traits with insignificant differences between biochar and biochar+ barley straw treatments. The highest yielding treatments under high drought stress $\left(55 \% \mathrm{ETc}, \mathrm{D}_{\mathrm{H}}\right)$ level were both $\mathrm{BCH}$ and $\mathrm{BCH}+\mathrm{ST}$ treatments. As for stress tolerance indices, $\mathrm{BCH}+\mathrm{ST}$ followed by $\mathrm{BCH}$ treatment recorded the highest Relative drought index "RDI", Stress Tolerance Index "STI", Geometric mean productivity "GMP", Yield Index "YI", Drought resistance

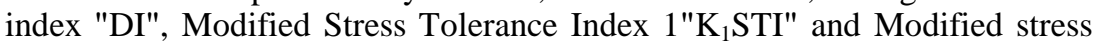
tolerance index 2 "K $\mathrm{K}_{2} \mathrm{STI"}$ suggesting more stress tolerance mechanism. Based on the yield category, treatments classified into three groups: high, moderate and low yield/feddan. Comparison between the two drought stress levels $\left(D_{H}\right.$ and $\left.\mathrm{D}_{\mathrm{M}}\right)$ shows the extent of improvement in the $75 \%$ ETc $\left(\mathrm{D}_{M}\right)$. Construction of dendrogram based on 12 drought tolerance indices under non-stress and both high and moderate drought conditions were involved. Based on Fruit yield (ton/fed) under non-stress and high drought stress, the 4-amendment treatments split into two main clusters. Cluster I contained stress tolerant treatment that had low value of stress susceptibility (Biochar and Biochar+ST) indicating the best cluster for both growth conditions. Cluster II performed poorly in the reverse trend of tolerant-group. So, this study confirms the contribution of biochar to the sustainability of agriculture and water conservation.
\end{abstract}

\section{INTRODUCTION}

Tomato is an important vegetable crop in Egypt, which occupied the largest cultivation area as well as consumes large quantities of water among vegetables. In arid and semi-arid conditions water apportionment for agriculture is reducing steadily and adequate of irrigation water is not available in many parts of the world. Water scarcity denotes serious problems to world food security, where most of irrigated agricultural areas of the world are predicted to face hazard water crisis in the future. Thus, in semi-arid Mediterranean regions studied new irrigation strategies which can reduce consumption of water irrigation and increase productivity of agriculture and

\footnotetext{
* Corresponding author: E-mail address: mahmoud3870748@gmail.com https://doi.org/10.21608/sinjas.2021.96136.1049

(C) 2021 SINAI Journal of Applied Sciences. Published by Fac. Environ. Agric. Sci., Arish Univ. All rights reserved.
} 
other sectors depending on water (Costa $\boldsymbol{e t}$ $\boldsymbol{a l . ,}$ 2007). Tomato crop is highly sensitive to water stress, furthermore water deficit by $15 \%$ and $30 \%$ resulting in reduce net profits by $15 \%$ and $22 \%$, respectively (Obreza $\boldsymbol{e t}$ al., 1996) through influencing physiological processes involving photosynthesis and transpiration. However, available water is important restriction for plant productivity, generally affecting growth of roots and leaves, dry matter accumulation, photosynthesis and stomata conductance (Blum, 1997). Soils of Arish region is, in general, characterized as sandy soil, which is very poor in mineral nutrients, single grain structure, low moisture holding capacity, susceptibility to erosion as well as low levels of organic matter content and microorganisms. Many researchers studied many methods to solve these problems. Organic additions are capable to improve soil properties and plant growth in addition, applying biochar amendment enhanced nutrient availability, soil water holding capacity, soil physical and chemical properties as well as plant productivity (Ahmad et al., 2017). Therefore, depending on the intrinsical characteristics of each biochar type, its application has the potential to modify some soil properties, i.e., soil $\mathrm{pH}$, nutrients availability, waterholding capacity, bulk density and soil aggregation (Lehmann and joseph, 2015; Mary et al., 2016). The optimal application rate of biochar is not yet established, as it will vary between biochar types, soil types and target species. Moreover, under saline irrigation water, She $\boldsymbol{e t}$ al. (2018) reported that biochar amendment increased vegetative growth, quality parameters and yield. One recent example is the increase in tomato plant growth and quality of fruit, which showed a darker red color and higher sugar, acid, and vitamin $\mathrm{C}$ content after soil amendment with bamboo biochar produced at different temperatures (Suthar et al., 2018). Furthermore, biochar amendments increase growth, quality, and crop yield under stress conditions such as salt and drought (Ali et al., 2017; Akhtar et al., 2018; She et al., 2018). Presently applications of organic amendments have become a more sustainable and current approach for increasing crop productivity under these conditions.

Straw application can supply nitrogen to the soil, reducing fertilizer nitrogen rates, so nitrogen pollution of agricultural ecosystems could be somewhat relieved (Watanabe et al., 2009). The decomposition of straw consumes inorganic soil nitrogen, reduces soil nitrogen leaching losses, and also, can reasonably maintain the soil $\mathrm{C} / \mathrm{N}$ ratio (Pan et al., 2013) and improve soil structure, especially in high-fertilizer-input fields (Yang et al., 2018). Straw is rich in cellulose, which is an ideal source of carbon and hydrogen for microorganisms inhabiting the soil (Chirak et al., 2017). Wyszkowska et al., (2021) confirmed the significant impact of an organic substance (finely ground barley straw) on organotrophic bacteria, oligotrophic spore-forming bacteria and actinobacteria.

Therefore, this study aims to determine the effects of water stress and organic soil amendments on some physical properties of soil, growth, yield and quality of tomato to maximize productivity and water saving under Arish region.

\section{MATERIALS AND METHODS}

Two field trials were carried out during successive two summer seasons of 2019 and 2020 at the Experimental Farm, Fac. Environ. Agric. Sci., Arish University, North Sinai, Egypt to study the influence of drought stress $\left(100 \%\right.$ ETc $\left(\mathrm{D}_{0}\right), 85 \%$ ETc $\left(\mathrm{D}_{\mathrm{L}}\right), 75 \%$ ETc $\left(\mathrm{D}_{\mathrm{M}}\right)$ and $55 \%$ ETc $\left(\mathrm{D}_{\mathrm{H}}\right)$ and organic amendments viz., biochar $(\mathrm{BCH})$, and barley straw (ST) on soil physical properties as well as growth, yield and quality of tomato. Biochar $(\mathrm{BCH})$ prepared from citrus wood $(\mathrm{CWB})$ in a traditional charcoal kiln (lump charcoal) 
was obtained from a local market (Elad $\boldsymbol{e t}$ al., 2010; Qayyum et al., 2015). Briefly, a porous black solid (consisting of an amorphous form of carbon) obtained as a residue when Citrus pruning offal is heated in the absence of air and it is figuratively called biochar. The biochar $(73.4 \% \mathrm{C}$, $0.63 \% \mathrm{~N}, 2.3 \% \mathrm{H}$, and $26.4 \% \mathrm{O}$ ) has been ground into a size of $\leq 2.0 \mathrm{~mm}$ (Suthar $\boldsymbol{e t}$ al., 2018). The prepared $\mathrm{BCH}$ was stored in clean plastic bags until use (Younis $\boldsymbol{e t}$ al., 2015). Seedlings of tomato $c v$. GS-12 $\mathrm{F}_{1}$ (produced by the Swiss Company Syngenta) were obtained from a commercial nursery (Arish, Egypt) at 40 to 50 days after seeding and transplanting was done on $15^{\text {th }}$ April. Organic amendments were applied after soil preparation and mixed in 15-20 $\mathrm{cm}$ of sandy loam soil surface $(7.5 \% \mathrm{pH}$, $0.16 \%$ organic matter (OM), $58.75 \%$ Coarse sand, $19.6 \%$ Fine sand, $12.84 \%$ silt, and $9.25 \%$ clay) at rates of 1.5 and 4.0 ton/fed for crashed barley straw (ST) and biochar $(\mathrm{BCH})$, respectively. However, after 15 days from transplanting, irrigation treatments were started. Treatments were all the combinations of four drought stress levels $\left(100 \%\right.$ ETc $\left(\mathrm{D}_{0}\right), 85 \%$ ETc $\left(\mathrm{D}_{\mathrm{L}}\right)$, $75 \%$ ETc $\left(\mathrm{D}_{\mathrm{M}}\right)$ and $55 \%$ ETc $\left.\left(\mathrm{D}_{\mathrm{H}}\right)\right)$ and four organic amendments, i.e., without amendments $\left(\mathrm{Am}_{0}\right)$ as control, crashed barley straw $\left(\mathrm{Am}_{\mathrm{S}}\right), \mathrm{CWB}$ biochar $\left(\mathrm{Am}_{\mathrm{CWB}}\right)$ and crashed barley straw + CWB biochar $\left(\mathrm{Am}_{\mathrm{S}+\mathrm{CWB}}\right)$. Treatments were arranged in a split-plot system with three replications in a Randomized Complete Block Design. Each replication comprised 16 sub-plots (four irrigation levels were randomly assigned to the main plots, where four amendment treatments were randomly arranged in the sub-plots) as shown in Table 1. The experimental unit area was $21.6 \mathrm{~m}^{2}$ (3 dripper lines $\times 6 \mathrm{~m}$ length $\times 1.2 \mathrm{~m}$ width), seedlings transplanted on dripper line $1.2 \mathrm{~m}$ apart and $0.5 \mathrm{~m}$ spaced between plants in the same line. One line was used to determine the morphological and physiological traits and the other two lines were used for yield determinations. In addition, one row, as guard area, was left between each two plots to avoid the overlapping infiltration of irrigation water. The normal agricultural practices of the commercial tomato production were done as needed. However, over two seasons mean of chemical analysis of irrigation water had EC $3.15 \mathrm{dS} / \mathrm{m}$ and $\mathrm{pH}$ 7.5.

\section{Recorded Data}

\section{Vegetative growth}

After 90 days from transplanting, 5 plants from each experimental unit were randomly taken to record plant height $(\mathrm{cm})$, leaf area/plant $\left(\mathrm{m}^{2}\right)$ and both fresh and dry total weight of plant.

\section{Leaf carotenoid and chlorophyll content}

The contents were extracted and measured by spectrophotometric (Marker and Jinks, 1982).

\section{Fruit yield}

It was calculated as average fruit weight (g), and total fruit yield (ton/fed).

\section{Fruit quality}

At ripe stage (red color), random sample of ten fruits were taken from each treatment to determine TSS $\%$, firmness $\left(\mathrm{Kg} / \mathrm{cm}^{2}\right)$ and fruit dry matter (\%) according to AOAC (1990).

\section{Leaves N, $P$ and $K$ contents}

$\mathrm{N}$ was determined using a microkjeldahl method (Jones et al., 1991), the total content of $\mathrm{K}$, and $\mathrm{P}$ were determined using a flame photometer device and the colorimetric method, respectively.

\section{Stress tolerance indices}

For each amendment treatment, twelve stress tolerance indices were calculated based on average yield under normal irrigation (Yn) and both medium and high drought stress (Ys) levels over the two seasons. The names, equations and references of the stress tolerance indices are shown in Table 2. A dendrogram was constructed based on "Euclidean distance" procedure. Amendment treatments were clustered using unweighted pair group method (UPGMA) using arithmetic average as outlined by Kovach (1995). 
Table 1. Irrigation regimes and organic amendments treatments used in this study

\begin{tabular}{|c|c|c|c|c|}
\hline \multirow{2}{*}{$\begin{array}{l}\text { Main plot } \\
\text { Irrigation regimes }\end{array}$} & \multicolumn{4}{|c|}{ Sub plot } \\
\hline & \multicolumn{4}{|c|}{ Organic amendments } \\
\hline $100 \% \operatorname{Etc}\left(D_{0}\right)$ & $\left(\mathrm{Am}_{0}\right)$ & $\left(\mathrm{Am}_{\mathrm{S}}\right)$ & $(\mathrm{AmCWB})$ & $\left(\mathrm{Am}_{\mathrm{S}}+\mathrm{CWB}\right)$ \\
\hline $80 \% \operatorname{Etc}\left(D_{L}\right)$ & $\left(\mathrm{Am}_{\mathrm{S}}+\mathrm{CWB}\right)$ & $(\mathrm{AmCWB})$ & $\left(\mathrm{Am}_{0}\right)$ & $\left(\mathrm{Am}_{\mathrm{S}}\right)$ \\
\hline $75 \% \operatorname{Etc}\left(\mathrm{D}_{M}\right)$ & $(\mathrm{AmCWB})$ & $\left(\mathrm{Am}_{\mathrm{S}}\right)$ & $\left(\mathrm{Am}_{\mathrm{S}}+\mathrm{CWB}\right)$ & $\left(\mathrm{Am}_{0}\right)$ \\
\hline $55 \% \operatorname{ETc}\left(D_{H}\right)$ & $\left(\mathrm{Am}_{0}\right)$ & $\left(\mathrm{Am} m_{S}+\mathrm{CWB}\right)$ & $\left(\mathrm{Am}_{\mathrm{S}}\right)$ & $(\mathrm{AmCWB})$ \\
\hline
\end{tabular}

$\mathbf{D}_{\mathbf{0}}$ : Full irrigation (control), $\mathbf{D}_{\mathbf{L}}, \mathbf{D}_{\mathbf{M}}$ and $\mathbf{D}_{\mathbf{H}}$ : Low, medium and high drought stress, respectively

$\mathbf{A m}_{\mathbf{0}}$ : without any amendments $\mathbf{A m}_{\mathrm{S}}$ : straw, $\mathbf{A m}_{\mathrm{CWWB}_{\mathbf{B}}}$ : Biochar, $\mathbf{A m}_{\mathbf{S}+\mathbf{C W B}}$ : straw+ Biochar treatments

Table 2. List of the drought stress tolerance indices and formula.

A. The high values of these indices indicated to stress tolerance

\begin{tabular}{|c|c|c|c|c|c|c|c|}
\hline Index & $\begin{array}{c}\text { Geometric } \\
\text { mean } \\
\text { productivity }\end{array}$ & $\begin{array}{c}\text { Relative } \\
\text { drought index }\end{array}$ & $\begin{array}{c}\text { Stress } \\
\text { Tolerance } \\
\text { Index }\end{array}$ & $\begin{array}{l}\text { Yield } \\
\text { Index }\end{array}$ & $\begin{array}{l}\text { Drought } \\
\text { resistance } \\
\text { index }\end{array}$ & $\begin{array}{l}\text { Modified } \\
\text { Stress } \\
\text { Tolerance } \\
\text { Index } 1\end{array}$ & $\begin{array}{l}\text { Modified } \\
\text { stress } \\
\text { tolerance } \\
\text { index } 2\end{array}$ \\
\hline Abbr. & GMP & RDI & STI & YI & DI & STIK $_{1}$ & STIK $_{2}$ \\
\hline Formula & $\sqrt{ } \mathrm{Yn} \times \mathrm{Ys}$ & $\frac{(\mathrm{Ys} / \mathrm{Yn})}{(\overline{\mathrm{Y}} s / \overline{\mathrm{Y}} n)}$ & $\begin{array}{c}(\mathrm{Ys} \times \mathrm{Yn}) / \\
(\overline{\mathrm{Y}} \mathrm{n})^{2}\end{array}$ & $\mathrm{Ys} / \overline{\mathrm{Y}} \mathrm{s}$ & $\begin{array}{c}(\mathrm{Ys} \times(\mathrm{Ys} / \mathrm{Yn})) / \\
\overline{\mathrm{Y}} \mathrm{s}\end{array}$ & $\begin{array}{c}{\left[(\mathrm{Yn})^{2} /(\overline{\mathrm{Y}} \mathrm{n})^{2}\right]} \\
\times \mathrm{STI}\end{array}$ & $\begin{array}{c}{\left[(\mathrm{Ys})^{2} /(\overline{\mathrm{Y}} \mathrm{s})^{2}\right] \times} \\
\text { STI }\end{array}$ \\
\hline References & $\begin{array}{c}\text { Fernandez } \\
(1992)\end{array}$ & $\begin{array}{l}\text { Fischer and } \\
\text { Wood (1979) }\end{array}$ & $\begin{array}{c}\text { Fernandez } \\
\text { (1992) }\end{array}$ & $\begin{array}{c}\text { Gavuzzi } \\
\text { et al. } \\
(1997)\end{array}$ & Lan (1998) & \multicolumn{2}{|c|}{ Farshadfar and Sutka (2002) } \\
\hline
\end{tabular}

B. The high values of these indices indicated to stress susceptibility

\begin{tabular}{cccccc}
\hline Index & $\begin{array}{c}\text { Stress } \\
\text { tolerance } \\
\text { index }\end{array}$ & $\begin{array}{c}\text { Stress } \\
\text { susceptibility } \\
\text { index }\end{array}$ & $\begin{array}{c}\text { Relative } \\
\text { decrease in } \\
\text { yield }\end{array}$ & Abiotic tolerance index & $\begin{array}{c}\text { Stress Susceptibility } \\
\text { percentage index }\end{array}$ \\
\hline Abbr. & TOL & SI & RDY & ATI & SSPI \\
\hline Formula & Yn $-\mathrm{Ys}$ & $\frac{1-(\mathrm{Ys} / \mathrm{Yn})}{1-(\overline{\mathrm{Y}} / \overline{\mathrm{Y}} \mathrm{n})}$ & $\begin{array}{c}100-(\mathrm{Ys} / \mathrm{Yn} \\
\times 100)\end{array}$ & $\begin{array}{c}{[(\mathrm{Yn}-\mathrm{Y} \mathrm{s}) /(\overline{\mathrm{Y}} \mathrm{n} / \mathrm{Y} s)]} \\
\times \sqrt{\mathrm{Y} n} \times \mathrm{Ys}\end{array}$ & {$[(\mathrm{Yn}-\mathrm{Ys}) /(2 \times \overline{\mathrm{Y}} \mathrm{n})] \times 100$} \\
\hline References & $\begin{array}{c}\text { Rosielle and } \\
\text { Hamblin } \\
(\mathbf{1 9 8 1})\end{array}$ & $\begin{array}{c}\text { Fischer and } \\
\text { Maurer } \\
(\mathbf{1 9 7 8})\end{array}$ & $\begin{array}{c}\text { Farshadfar } \\
\text { et al.(2013) }\end{array}$ & Moosavi et al. (2008) & Moosavi et al. (2008)
\end{tabular}

Ys and Yn: Yield of each amendment treatment under stress and non-stress conditions, respectively.

$\hat{Y} s$ and $\hat{Y} n$ : Mean of yield overall treatments under stress and non-stress conditions, respectively. 
Statistical analysis of the obtained data was carried out according to Snedecor and Cochran (1980). Duncan's multiple range tests was used for comparison among means (Duncan, 1955).

\section{RESULTS AND DISCUSSION}

\section{Effect of Irrigation Regimes}

Results in Table 3 and Fig. 1 indicate that irrigation treatments had significant effect on plant height, both fresh and dry plant weights and leaf area of tomato in the two seasons.

It could be inferred that full water levels $(100 \%$ ETc) produced the maximum plant height, both fresh and dry weight of plant and leaf area as vegetative growth traits, fruit firmness $\left(\mathrm{Kg} / \mathrm{cm}^{2}\right)$ and fruit dry matter (\%) as fruit quality as well as both average fruit weight and total fruit yield of tomato in both seasons with no significant differences among 100, 85 and 75\% ETc irrigation levels at both seasons for vegetative traits and $1^{\text {st }}$ one for both average fruit weight and firmness. Water deficit treatment improved the TSS \% of tomato fruits (Fig. 2) compared with full irrigation treatment, this result is in accordance with that of Singh et al. (2019). Agbna et al. (2017) reported a insignificantly increase in TSS\% of tomato fruits and water stressed plants had higher values for most quality traits compared with the unstressed plants. On the contrary, the lowest values of all vegetative and yield previously mentioned parameters were recorded under high drought stress $(55 \%$ ETc), where, the decreases in total yield (average of two seasons) were about 18.8, 36.6 and $46.9 \%$ due to irrigation with 85, 75 and $55 \%$ ETc than full irrigation $(100 \%$ ETc $)$. High drought stress $(55 \%$ ETc) caused a reduction in all studied plant growth characters, and this may be due to that water stress causes losses in tissues content of water which led to reduce the turgor pressure in the cells, thereby inhibition enlargement and cell division as concluded by Hsiao et al., (1974). Water stress causes an increase in Abscisic Acid (ABA) / Cytokinin (CYT) ratio, which in turn decreased plant growth (Marschner, 1995), where ABA is decreasing, under sufficient water conditions, with increasing in CYT, Gibberellic Acid (GA) and Indole Acetic Acid (IAA) reflecting good growth and dry matter content (Fig. 2).

The increment in water supply led to increase the soil moisture content and caused no suffering of plants to get their water requirements, where primarily irrigation improves leaves growth which in turn increases net assimilation of organic nutrients and subsequently plant growth and yield.

Results showed that, low water supply content resulted in decreased root growth and inhibited leaf enlargement rate associated with increase in ABA concentration in leaves as reported by Smith and Dale (1988) and decreasing CYT production and export (Atkin et al., 1973). Also, harmful effect of drought could be due to negatively effects on cell division and enlargement, reduces photosynthetic rate, delay cellular growth, and finally this in turn affect the growth and yield of tomato plants (Hafez et al., 2020). Increasing yield with increasing irrigation level might be due to the increase of total chlorophyll content and/or the increment of leaf transpiration, which correlates with the increasing water supply results in a positive effect on yield via the enhancing gases exchange and photosynthesis process (Foti et al. 1995).

\section{Effect of Soil Amendments}

Application of biochar and barley straw (alone or in combination) significantly increased vegetative growth traits (both fresh and dry total plant weight and leaf area) and total fruit yield of tomato (Table 4 and Fig. 3). Biochar plus barley straw $(\mathrm{BCH}+\mathrm{ST})$ treatment exhibited the highest value for all abovementioned traits followed by $\mathrm{BCH}$ alone with no significant differences between $\mathrm{BCH}$ and ST in all these traits, except total plant fresh weight and total fruit yield at both seasons and first one, respectively. 


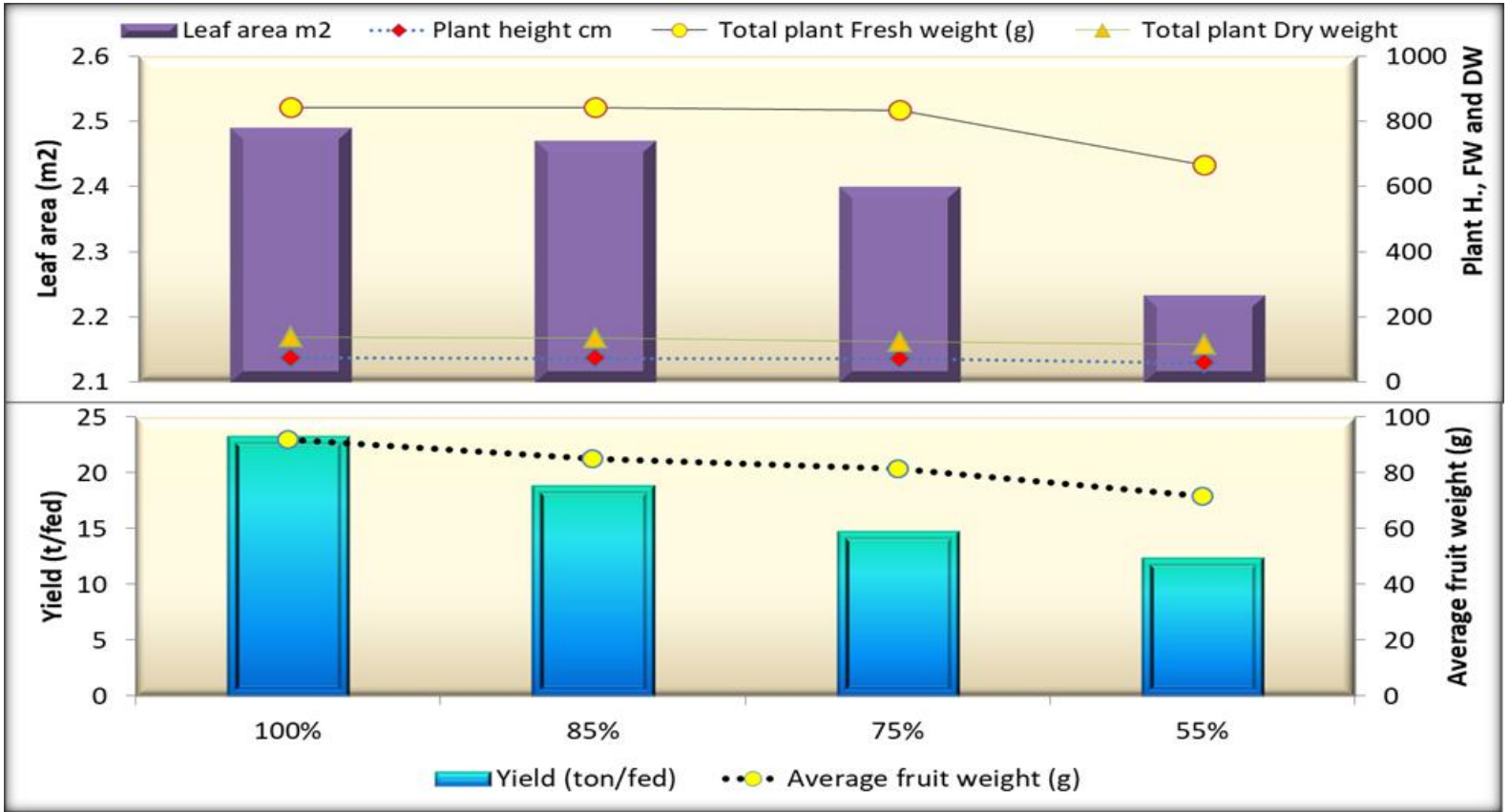

Fig. 1. Vegetative growth (Upper), average fruit weight (g) and fruit yield (ton/fed) (Down) traits of tomato as affected by irrigation regimes (average of two seasons)

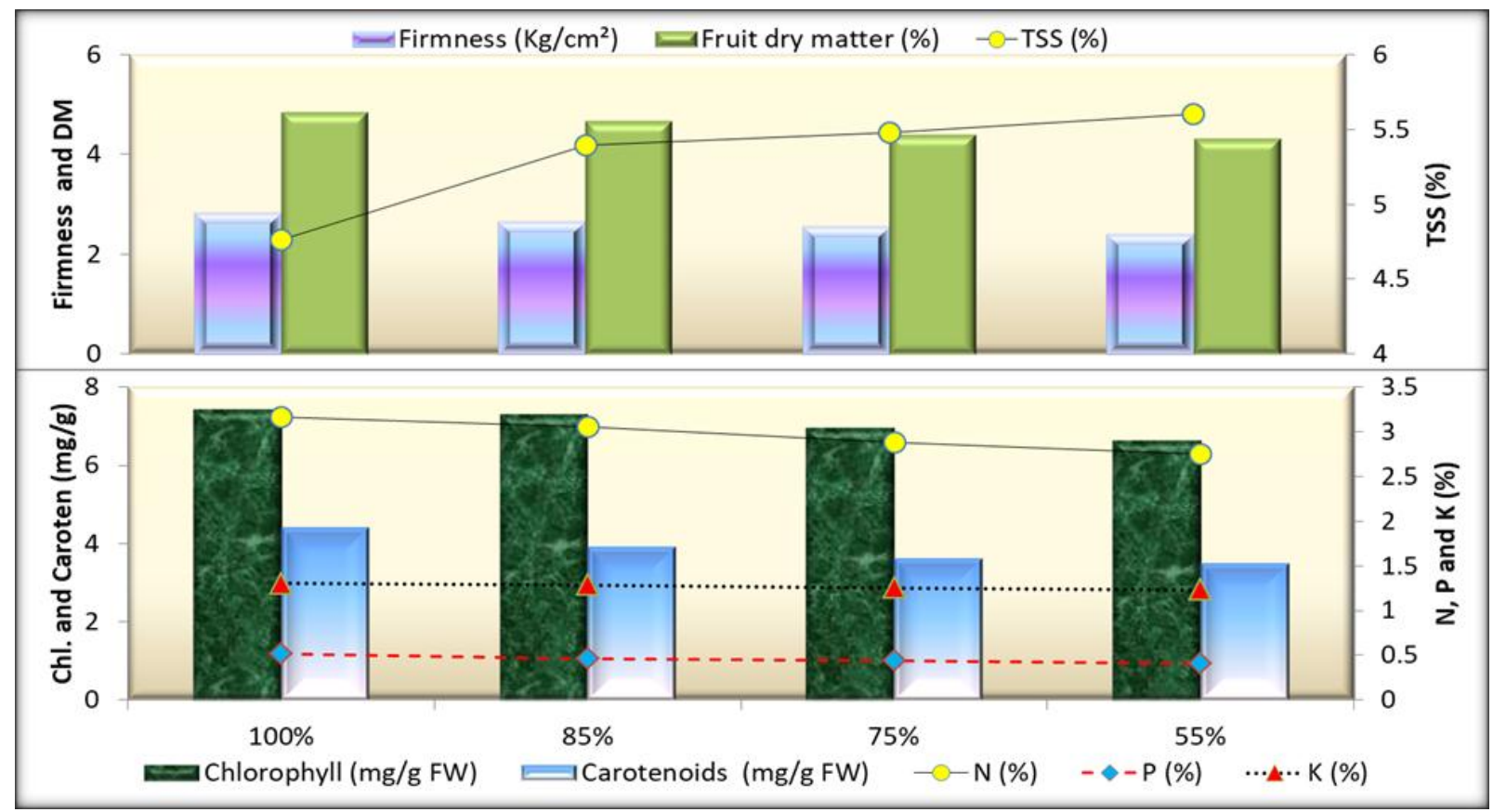

Fig.2. Tomato fruit quality (Upper), leaf content of chlorophyll and carotenoids as well as chemical constituent (Down) as affected by irrigation regimes (average of two seasons). 
Table 3. Vegetative growth, average fruit weight (g) and fruit yield of tomato (ton/fed.) as affected by irrigation regimes during two seasons

\begin{tabular}{|c|c|c|c|c|c|c|}
\hline \multirow{2}{*}{$\begin{array}{c}\text { Irrigation } \\
\text { regimes }\end{array}$} & \multirow{2}{*}{$\begin{array}{l}\text { Plant height } \\
(\mathrm{cm})\end{array}$} & \multicolumn{2}{|c|}{ Total plant weight (g) } & \multirow{2}{*}{$\begin{array}{c}\text { Leaf area } \\
\left(\mathbf{m}^{2}\right)\end{array}$} & \multirow{2}{*}{$\begin{array}{l}\text { Average fruit } \\
\text { weight (g) }\end{array}$} & \multirow{2}{*}{$\begin{array}{l}\text { Total fruit yield } \\
\quad \text { (ton/fed) }\end{array}$} \\
\hline & & Fresh & Dry & & & \\
\hline \multicolumn{7}{|c|}{$1^{\text {st }}$ season } \\
\hline $100 \%$ & $73.16 \mathrm{a}$ & $843.08 \mathrm{a}$ & $136.36 \mathrm{a}$ & $2.48 \mathrm{a}$ & $92.16 \mathrm{a}$ & $22.37 \mathrm{a}$ \\
\hline $85 \%$ & $70.71 \mathrm{a}$ & $838.48 \mathrm{a}$ & $133.37 \mathrm{a}$ & $2.46 \mathrm{a}$ & $83.64 a b$ & $17.93 b$ \\
\hline $75 \%$ & $69.46 \mathrm{a}$ & $831.44 a$ & $122.57 \mathrm{ab}$ & $2.39 \mathrm{a}$ & $80.75 \mathrm{ab}$ & $13.72 \mathrm{c}$ \\
\hline $55 \%$ & $55.05 \mathrm{~b}$ & $663.86 \mathrm{~b}$ & $112.81 \mathrm{~b}$ & $2.22 b$ & $67.91 \mathrm{~b}$ & $11.52 \mathrm{c}$ \\
\hline \multicolumn{7}{|c|}{$2^{\text {nd }}$ season } \\
\hline $100 \%$ & $74.77 \mathrm{a}$ & $845.36 \mathrm{a}$ & $139.28 \mathrm{a}$ & $2.50 \mathrm{a}$ & $91.78 \mathrm{a}$ & $24.23 \mathrm{a}$ \\
\hline $85 \%$ & $73.18 \mathrm{a}$ & $844.78 \mathrm{a}$ & $136.09 a$ & $2.48 \mathrm{a}$ & $86.12 \mathrm{a}$ & $19.93 b$ \\
\hline $75 \%$ & $71.36 \mathrm{a}$ & $835.54 \mathrm{a}$ & $126.23 \mathrm{ab}$ & $2.41 \mathrm{a}$ & $82.32 \mathrm{a}$ & $15.85 \mathrm{c}$ \\
\hline $55 \%$ & $59.51 \mathrm{~b}$ & $668.95 b$ & $116.19 \mathrm{~b}$ & $2.25 \mathrm{~b}$ & $75.41 \mathrm{a}$ & $13.27 \mathrm{c}$ \\
\hline
\end{tabular}

- Values having the same alphabetical letter(s) did not significantly differ at 0.05 level of probability according to Duncan's multiple range test.

Table 4. Vegetative growth, average fruit weight (g) and fruit yield of tomato (ton/fed) as affected by organic amendments during two seasons

\begin{tabular}{ccccccc}
\hline $\begin{array}{c}\text { Organic } \\
\text { amendments }\end{array}$ & $\begin{array}{c}\text { Plant height } \\
(\mathbf{c m})\end{array}$ & \multicolumn{2}{c}{ Total plant weight $(\mathbf{g})$} & $\begin{array}{c}\text { Leaf area } \\
\left(\mathbf{m}^{2}\right)\end{array}$ & $\begin{array}{c}\text { Average fruit } \\
\text { weight }(\mathbf{g})\end{array}$ & $\begin{array}{c}\text { Total fruit yield } \\
\text { (ton/fed) }\end{array}$ \\
\cline { 3 - 5 } Control & $56.47 \mathrm{c}$ & $739.18 \mathrm{c}$ & $111.69 \mathrm{c}$ & $1.99 \mathrm{c}$ & $77.18 \mathrm{a}$ & $13.58 \mathrm{c}$ \\
$\mathbf{S T}$ & $63.28 \mathrm{bc}$ & $777.79 \mathrm{~b}$ & $122.61 \mathrm{~b}$ & $2.37 \mathrm{~b}$ & $81.55 \mathrm{a}$ & $15.46 \mathrm{~d}$ \\
$\mathbf{B C H}$ & $69.22 \mathrm{~b}$ & $819.56 \mathrm{a}$ & $131.72 \mathrm{ab}$ & $2.42 \mathrm{~b}$ & $82.55 \mathrm{a}$ & $17.20 \mathrm{~b}$ \\
$\mathbf{B C H + S T}$ & $79.42 \mathrm{a}$ & $840.34 \mathrm{a}$ & $139.10 \mathrm{a}$ & $2.76 \mathrm{a}$ & $83.19 \mathrm{a}$ & $19.31 \mathrm{a}$ \\
& & & $\mathbf{2}^{\text {nd }} \mathbf{s e a s o n}$ & & & \\
Control & $59.94 \mathrm{~b}$ & $741.52 \mathrm{a}$ & $114.67 \mathrm{c}$ & $2.01 \mathrm{c}$ & $79.94 \mathrm{a}$ & $15.62 \mathrm{c}$ \\
$\mathbf{S T}$ & $65.44 \mathrm{~b}$ & $782.07 \mathrm{a}$ & $126.27 \mathrm{~b}$ & $2.39 \mathrm{~b}$ & $83.12 \mathrm{a}$ & $17.46 \mathrm{~b}$ \\
$\mathbf{B C H}$ & $71.40 \mathrm{ab}$ & $826.75 \mathrm{a}$ & $134.67 \mathrm{ab}$ & $2.44 \mathrm{~b}$ & $85.67 \mathrm{a}$ & $19.03 \mathrm{~b}$ \\
$\mathbf{B C H + S T}$ & $82.02 \mathrm{a}$ & $844.28 \mathrm{~b}$ & $142.18 \mathrm{a}$ & $2.79 \mathrm{a}$ & $86.89 \mathrm{a}$ & $21.19 \mathrm{a}$ \\
\hline
\end{tabular}

- Values having the same alphabetical letter(s) did not significantly differ at 0.05 level of probability according to Duncan's multiple range test. 


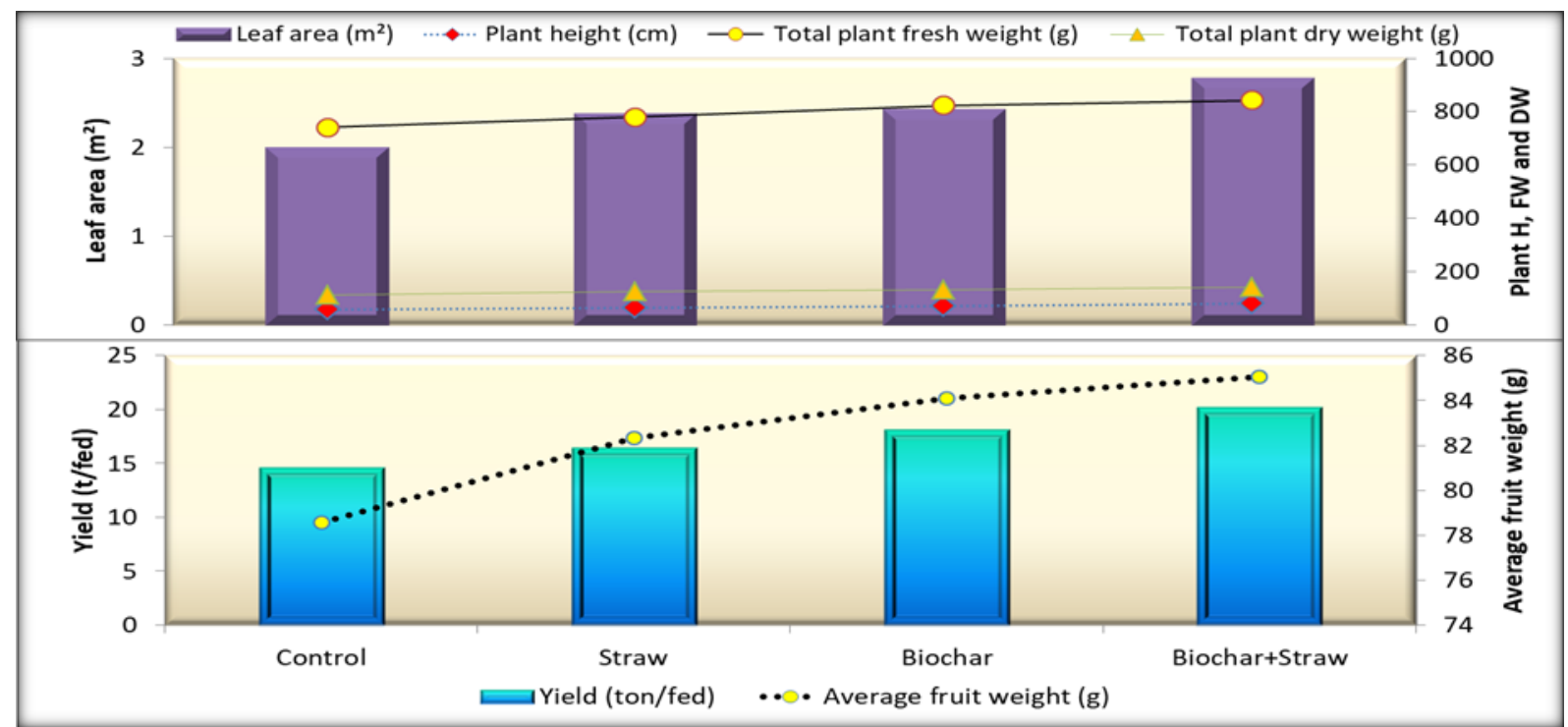

Fig. 3. Tomato vegetative growth (Upper), average fruit weight (g) and fruit yield (ton/fed) (Down) traits as affected by organic amendments (average of two seasons)

It was reported that biochar application, also gradually and insignificantly improved the fruit TSS (\%) (Singh et al., 2019). Leaves content of total chlorophyll, carotenoids and chemical constituents as well as fruit quality (firmness, TSS\% and dry matter) are shown in Fig.4. results showed significant effects for soil amendment treatments on all studied traits in both seasons, except, leaves content of chlorophyll in the first season. The highest content of photosynthetic pigments (chlorophyll and carotene) were recorded with application of biochar plus barley straw without significant differences than application of biochar alone in both seasons.

The positive effect of biochar can be attributed to the fact that biochar increases the soil content of elements such as carbon that improves soil quality and leads to an increase in the relative water content and enhancement of plant traits. This result of biochar application was similar to the results obtained by Wei et al. (2020). The increase in these traits may be due to the important role of biochar in enhancing nutrient and water use efficiency, the mechanisms responsible for increasing nutrient availability, increased cation exchange capacity and surface area leading to nutrient retention or direct release from the elements adsorbed from the biochar surfaces (Mukome et al., 2013). As well as more effective of biochar or straw in reducing soil temperature compared to the control (Chakraborty et al., 2008).

\section{Drought Stress and Organic Amendments Interaction $(\mathrm{D} \times \mathrm{Am})$ :}

As previously mentioned, the plants that received $55 \%$ ETc water irrigation $\left(\mathrm{D}_{\mathrm{H}}\right)$ showed the minimum vegetative growth values and yield traits (Table 3) compared with the plants received $75 \%$ ETc $\left(D_{M}\right)$ and $85 \%$ ETc $\left(\mathrm{D}_{\mathrm{L}}\right)$ deficit irrigations and wellwatered plants (100\% ETc). However, treated stressed plants with biochar and/or barley straw significantly increased most vegetative growth traits as well as total fruit yield/fed under drought conditions in the 


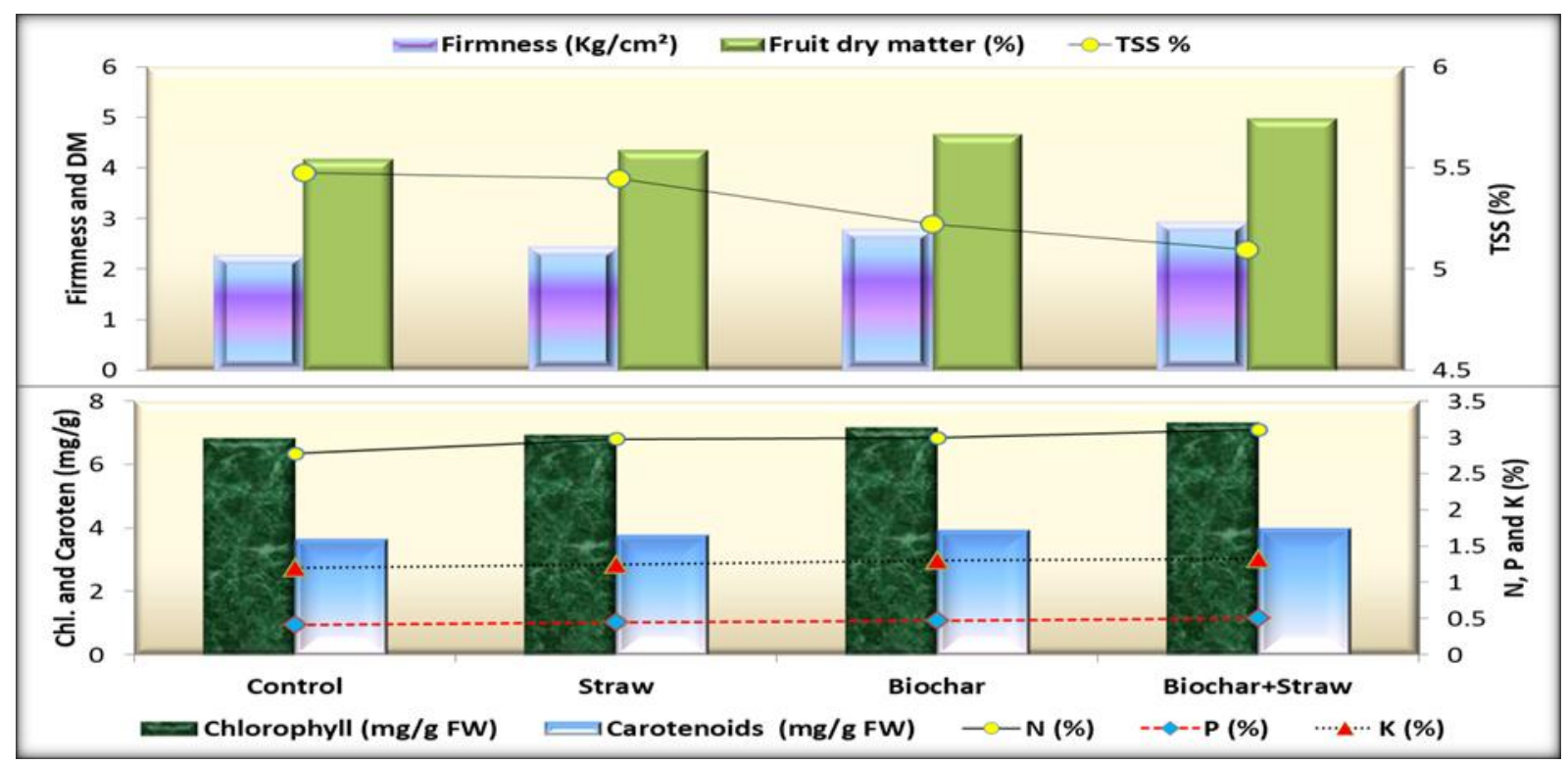

Fig. 4. Tomato fruit quality (Upper), leaf content of chlorophyll and carotenoids as well as chemical constituent (Down) as affected by irrigation regimes (average of two seasons)

two seasons (Figs. 5 and 6). Among all treatments, the high values were recorded in the stressed tomato plants which treated with biochar plus barley straw $\left(\mathrm{Am}_{\mathrm{CWB}+\mathrm{S}}\right)$ followed by biochar $\left(\mathrm{Am}_{\mathrm{CWB}}\right)$ alone comparing with corresponding control (stressed untreated plants) in both seasons. However, no significant difference between the interaction of organic amendments and drought stress treatments $(\mathrm{D} \times \mathrm{Am})$ with the control (well-watered plants) was observed for average fruit weight in the two seasons. The lowest values of vegetative growth and yield traits were recorded with the interaction between untreated plants and $55 \%$ ETc stressed plants $\left(\mathrm{Am}_{0} \times \mathrm{D}_{\mathrm{H}}\right)$ for all traits in both seasons.

As mentioned above, the fruit yield and firmness traits values (Figs. 6 and 7) of tomato plants significantly increased with application of biochar $\left(\mathrm{Am}_{\mathrm{CWB}}\right)$ and biochar plus straw $\left(\mathrm{Am}_{\mathrm{CWB}+\mathrm{ST}}\right)$ as well as fruit dry matter in case of $\mathrm{Am}_{\mathrm{CWB}+\mathrm{ST}}$ where the increase was significant in the stressed (55 and $75 \%$ ETc) treated plants compared with stressed (55 and $75 \%$ ETc) untreated plants. These results could be attributed to the important role of organic amendments in improving plant growth, increase nutrients uptake, enhance the concentrations of phytohormones (Hussain et al., 2008), and consequently improve yield characters (Langeroodi et al., 2019). However, TSS performed in the same trend where plants of amended soil exposed to water stress treatments had higher values compared with the unstressed plants.

\section{Soil Water Relation}

Field capacity (FC), plant permanent wilting point (PWP) and plant available water content (AWC) as soil moisture parameters were evaluated and compared to quantify soil water holding capacity. Significant increases in FC and AWC were observed in the three organic amendments (crashed barley straw, biochar and crashed barley straw + biochar) treatments, where the wilting point only slightly increased. However, biochar + barley treatment exhibited the highest increment under all water levels of the three water relation traits with no significant differences between biochar and biochar + barley straw treatments (Fig. 8 ). 


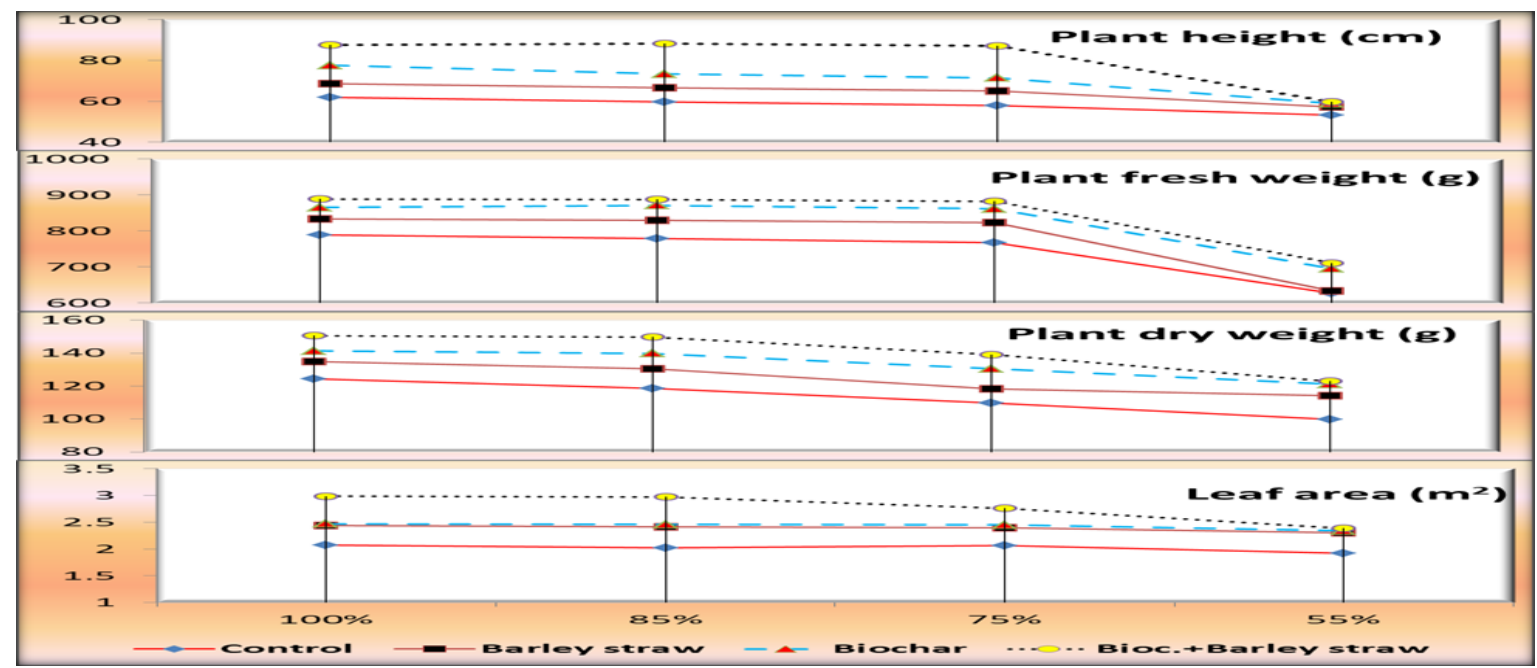

Fig.5: Vegetative growth traits of tomato plants as affected by the interaction between irrigation regimes and amendments (average of both seasons).

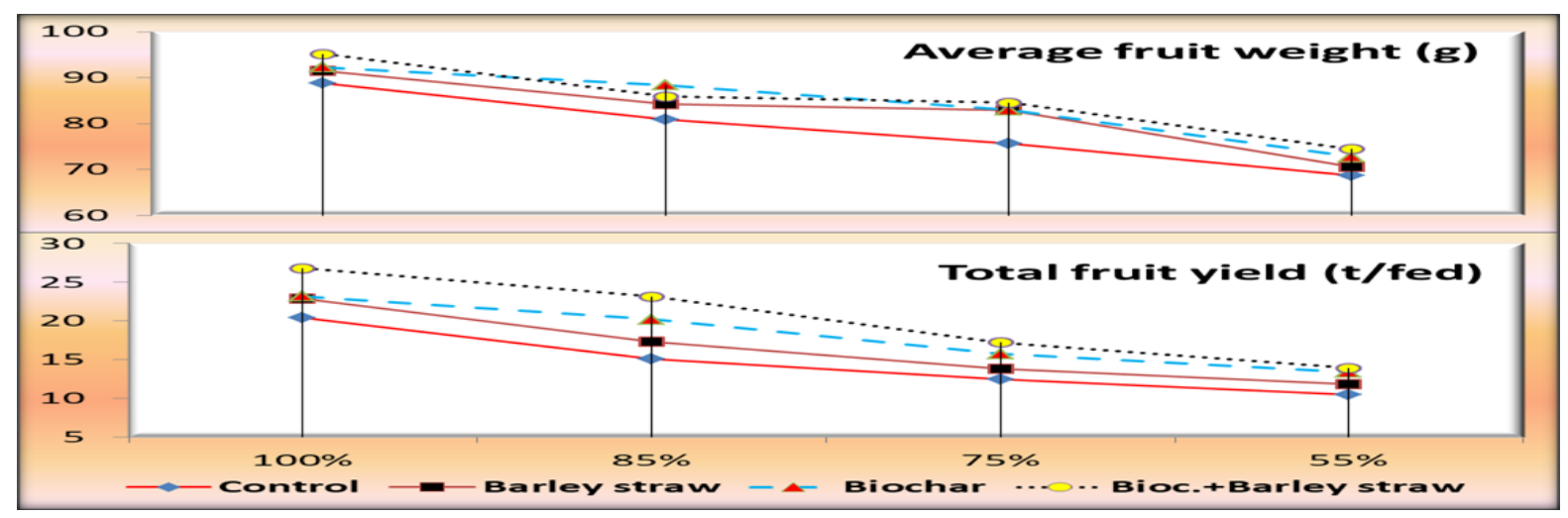

Fig.6. Yield traits of tomato plants as affected by the interaction between irrigation regimes and amendments (average of both seasons)

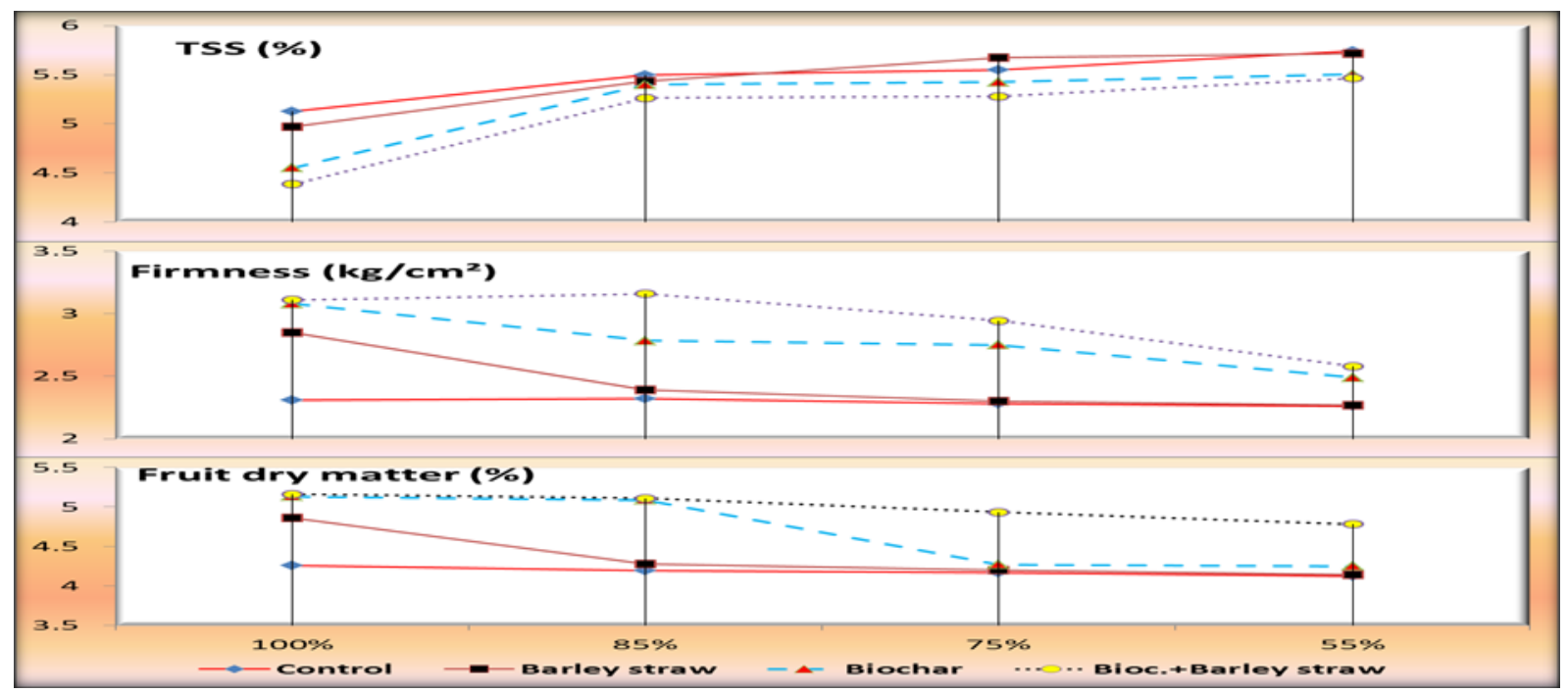

Fig.7. Fruit quality traits of tomato as affected by the interaction between irrigation regimes and amendments (average of both seasons) 


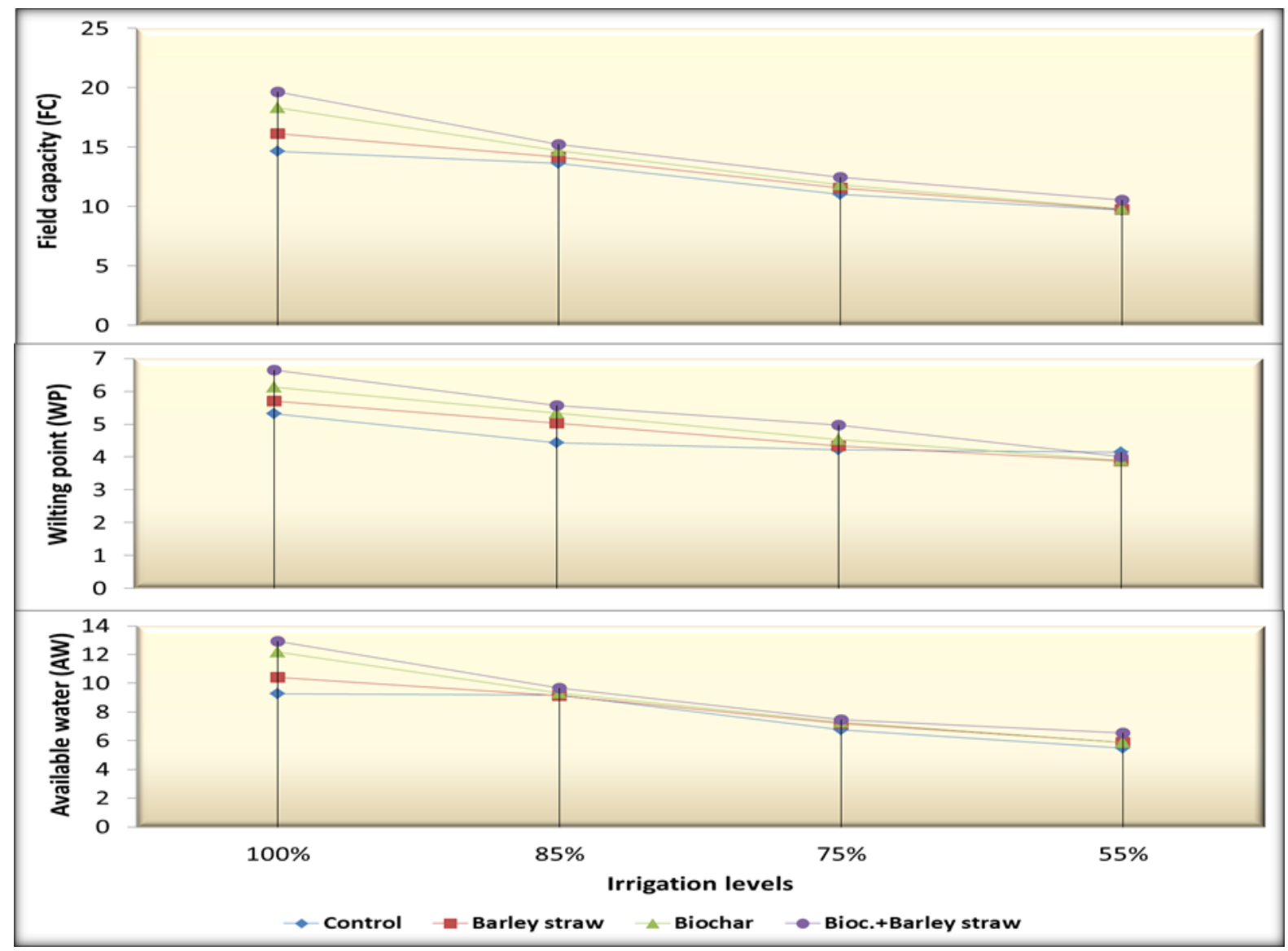

Fig. 8. Soil field capacity (\%) "Upper", wilting point $(\%)$ "Middle" and available water (\%) "Down"as affected by irrigation regimes (average of both seasons)

The plant permanent wilting point (PWP) is closely related to the specific surface area of soil, whereas the plant available water content (AWC) does not depend on it (Petersen et al., 2016). Fig. 8 show that AWC of the experimental soil (sandy loam) was about $11.21 \%$ as average of both seasons that is in line with Li et al., (2021).

Any methods to improve field capacity and reduce the wilting point will increase the water available to plants (modifying the soil structure towards higher porosity with smaller pore sizes (Li et al., 2021). It has been reported that biochar additions can transform the drainable pores between soil particles into water-retaining pores, and thus, the plant AWC of sandy loam soils with biochar additions was significantly increased (Petersen et al., 2016). The increase in AWC was affected by the amount of biochar added and the biochar particle size. There is strong controversy regarding the effects of biochar as an additive to sandy soils. Several studies have shown positive effects of biochar on soil water retention and others have failed to provide promising results. Biochar can change the texture of sandy soils and soil moisture parameters and provide a water storage mechanism. Because of the inconsistent research results, it is worth understanding the functions and mechanisms of biochar in modulating water retention and nutrition for sandy soils from a fluid mechanics point of view (Li et al., 2021). 


\section{Stress Tolerance indices}

Results of Fig. 6 show that the highest yielding treatments under normal irrigation (100\% ETc) were BCH (23.165 ton/fed) and $\mathrm{BCH}+\mathrm{ST}$ (26.77 ton/fed), whereas ST alone had the least value (22.845 ton/fed). However under water stress $(55 \%$ ETc), both $\mathrm{BCH}$ (13.36 ton/fed) and $\mathrm{BCH}+\mathrm{ST}$ (13.91 ton/fed) treatments had the highest fruit yield. Meanwhile, barley straw (ST) treatment gave the least value (11.87 ton/ fed) with the highest reduction percentage (42.9\%) comparing with control treatment (without amendments, 20.43 ton/fed). According to the mean productivity index (MP), the highest value of MP recorded by $\mathrm{BCH}+\mathrm{ST}$ treatment (17.17 ton/fed) as average of both normal and water deficit conditions, whereas, the least value was expressed by barley straw (ST) treatment alone. Treatments that had high yield under normal and stressed irrigation condition, had high values of MP index (Farshadfar and Sutka, 2002), while, Shirazi et al. (2009) stated that the higher yield in the non-stress condition resulted in an increase in the MP index and cannot be considered a valid indicator for identifying treatments that reduce the effect of stress. As shown in Fig. 9 and Table 5, BCH+ST amendment treatment followed by $\mathrm{BCH}$ treatment recorded the highest RDI, STI, GMP, YI, DI, $\mathrm{K}_{1} \mathrm{STI}$ and $\mathrm{K}_{2} \mathrm{STI}$ as compared with other amendment treatments suggesting more stress tolerance mechanism, where, treatments exhibited high values of STI showed high MP and GMP. Moreover, STI was more useful index in order to select favorable treatments under stress and nonstress conditions (Moghaddam and HadiZadeh 2002). Therefore, selection based on STI might lead to high-yielding treatments (Abdelghany et al., 2016).
Based on the STI under drought tolerance of $55 \%$ of ETc, treatments were classified into three groups: highly tolerant to drought stress $(2, \mathrm{HT})$, susceptible $(1, \mathrm{~S})$ and highly susceptible (1, HS) (Table 5). The stress tolerance index (STI) does not take into account the low relative yield under drought stress, thus a treatment classified as highly tolerant based on the STI value may have a high percentage of yield decrease under drought stress which is undesirable. Therefore, the classification of the three classes of drought tolerance based on the STI value was improved by incorporating the relative decrease in yield under the drought (RDY) index (Table 6).

The selection methods involving the two selection criteria, STI and RDY are presented in Table 6. Based on this selection mode of the 4 treatments evaluated (including the control), two were drought tolerant and two highly drought susceptible. Based on the yield category, treatments classified into three groups: high (2, BCH and $\mathrm{BCH}+\mathrm{ST})$, moderate (1, ST) and low (1, without amendments) yield/ feddan.

As for moderate drought stress condition (75\% ETc), based on the stress tolerance indices values and productivity (Fig.10), the treatments exhibited more improvements under $75 \%$ ETc drought stress condition comparing with $55 \%$ ETc. Comparison between the two drought stress levels $\left(D_{H}\right.$ and $\mathrm{D}_{\mathrm{M}}$ ) shows the extent of improvement in the $75 \%$ ETc $\left(D_{M}\right)$. However, the yield of ST, BCH and $\mathrm{BCH}+\mathrm{ST}$ treated under $75 \%$ ETc increment by 16.26, 17.7 and 23.62\%, respectively compare with their productivity under 55\% ETc $\left(\mathrm{D}_{\mathrm{H}}\right)$ drought stress which caused it to be improved to a higher yield categories level (Table 5 and Fig. 10). 
Mahmoud, et al. | SINAI Journal of Applied Sciences 10 (2) $2021 \quad 067-088$
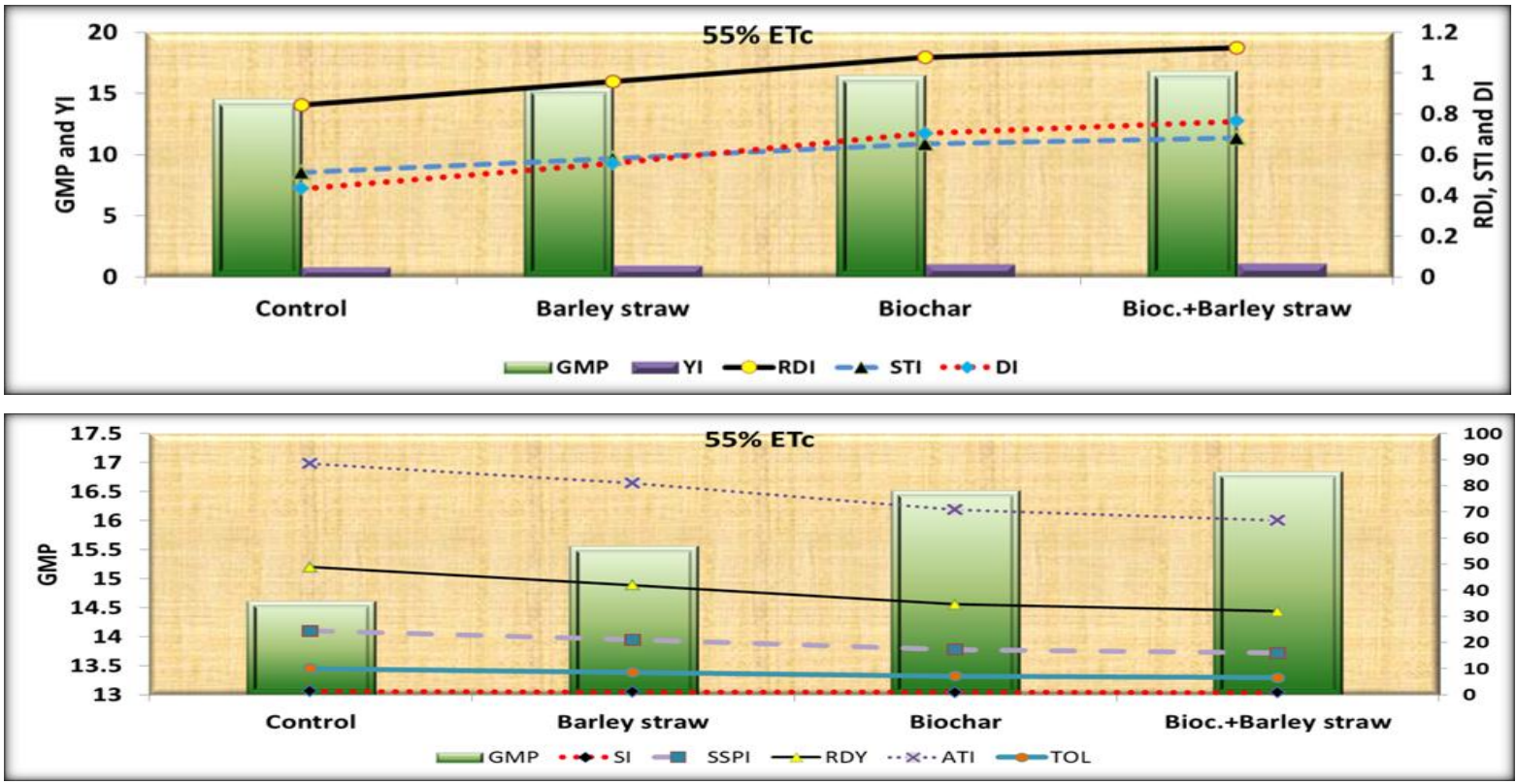

Fig. 9. Drought tolerance indices of yield under non-stress and 55\% ETc drought stress (average of both seasons)

Table 5. Drought tolerance indices for leaf area $\left(\mathrm{m}^{2}\right)$, average fruit weight (g) and total fruit yield (ton/fed.) under high drought, $D_{H}(55 \%$ ETc) stress conditions (average of both seasons)

\begin{tabular}{|c|c|c|c|c|c|c|c|c|c|c|c|c|}
\hline Item & RDI & STI & GMP & TOL & YI & DI & SSPI & RDY & $\overline{\text { ATI }}$ & $\mathrm{K}_{1} \mathrm{STI}$ & $\overline{\mathrm{K}_{2} \mathrm{STI}}$ & SI \\
\hline \multicolumn{13}{|c|}{ Leaf area $\left(\mathrm{m}^{2}\right)$} \\
\hline Control & 0.86 & 0.46 & 1.41 & 1.12 & 0.86 & 0.4 & 26.93 & 53.86 & 0.84 & 0.46 & 0.34 & 1.16 \\
\hline ST & 1.03 & 0.55 & 1.54 & 0.93 & 1.03 & 0.57 & 22.34 & 44.69 & 0.76 & 0.55 & 0.59 & 0.96 \\
\hline BCH & 1.05 & 0.56 & 1.55 & 0.91 & 1.05 & 0.59 & 21.86 & 43.72 & 0.75 & 0.56 & 0.62 & 0.94 \\
\hline $\mathrm{BCH}+\mathrm{ST}$ & 1.06 & 0.57 & 1.56 & 0.89 & 1.06 & 0.61 & 21.50 & 43.00 & 0.75 & 0.57 & 0.64 & 0.93 \\
\hline \multicolumn{13}{|c|}{ Average fruit weight (g) } \\
\hline Control & 0.96 & 0.77 & 78.16 & 20.04 & 0.96 & 0.74 & 11.28 & 22.56 & $1,263.39$ & 0.77 & 0.71 & 1.17 \\
\hline ST & 0.99 & 0.79 & 79.18 & 18.23 & 0.99 & 0.78 & 10.26 & 20.53 & $1,164.56$ & 0.79 & 0.77 & 1.06 \\
\hline BCH & 1.02 & 0.82 & 80.41 & 16.02 & 1.02 & 0.83 & 9.02 & 18.04 & $1,039.28$ & 0.82 & 0.85 & 0.93 \\
\hline $\mathbf{B C H}+\mathrm{ST}$ & 1.04 & 0.84 & 81.33 & 14.35 & 1.04 & 0.87 & 8.08 & 16.15 & 941.26 & 0.84 & 0.91 & 0.84 \\
\hline \multicolumn{13}{|c|}{ Total fruit weight(ton/fed.) } \\
\hline Control & 0.84 & 0.51 & 14.61 & 9.98 & 0.84 & 0.43 & 24.41 & 48.83 & 88.47 & 0.51 & 0.36 & 1.24 \\
\hline ST & 0.96 & 0.58 & 15.57 & 8.56 & 0.96 & 0.56 & 20.95 & 41.9 & 80.9 & 0.58 & 0.53 & 1.07 \\
\hline BCH & 1.08 & 0.65 & 16.52 & 7.07 & 1.08 & 0.70 & 17.30 & 34.61 & 70.89 & 0.65 & 0.76 & 0.88 \\
\hline $\mathrm{BCH}+\mathrm{ST}$ & 1.12 & 0.68 & 16.86 & 6.52 & 1.12 & 0.76 & 15.96 & 31.91 & 66.70 & 0.68 & 0.86 & 0.81 \\
\hline
\end{tabular}


Table 6. Mode for classifying treatments into four classes of drought resistance degree

\begin{tabular}{|c|c|c|}
\hline STI classification & Range of RDY & Selection \\
\hline \multirow{4}{*}{ HT } & $<25 \%$ & Highly drought Tolerant \\
\cline { 2 - 3 } & $>25<50 \%$ & Tolerant \\
\cline { 2 - 3 } & $>50<75 \%$ & Susceptible \\
\cline { 2 - 3 } & $>75<100 \%$ & Highly susceptible \\
\cline { 2 - 3 } & $>25 \%$ & Tolerant \\
\cline { 2 - 3 } & $>25<50 \%$ & Susceptible \\
\cline { 2 - 3 } & $>50<75 \%$ & Highly susceptible \\
\hline \multirow{4}{*}{ T } & $>5<100 \%$ & Highly susceptible \\
\cline { 2 - 3 } & $>25<5 \%$ & Highly susceptible \\
\cline { 2 - 3 } & $>50<75 \%$ & Highly susceptible \\
\hline \multirow{3}{*}{ HS } & $>75<100 \%$ & Highly susceptible \\
\cline { 2 - 3 } & $>25<50 \%$ & Highly susceptible \\
\cline { 2 - 3 } & $>50<75 \%$ & Highly susceptible \\
\cline { 2 - 3 } & $>75<100 \%$ & Highly susceptible \\
\hline
\end{tabular}
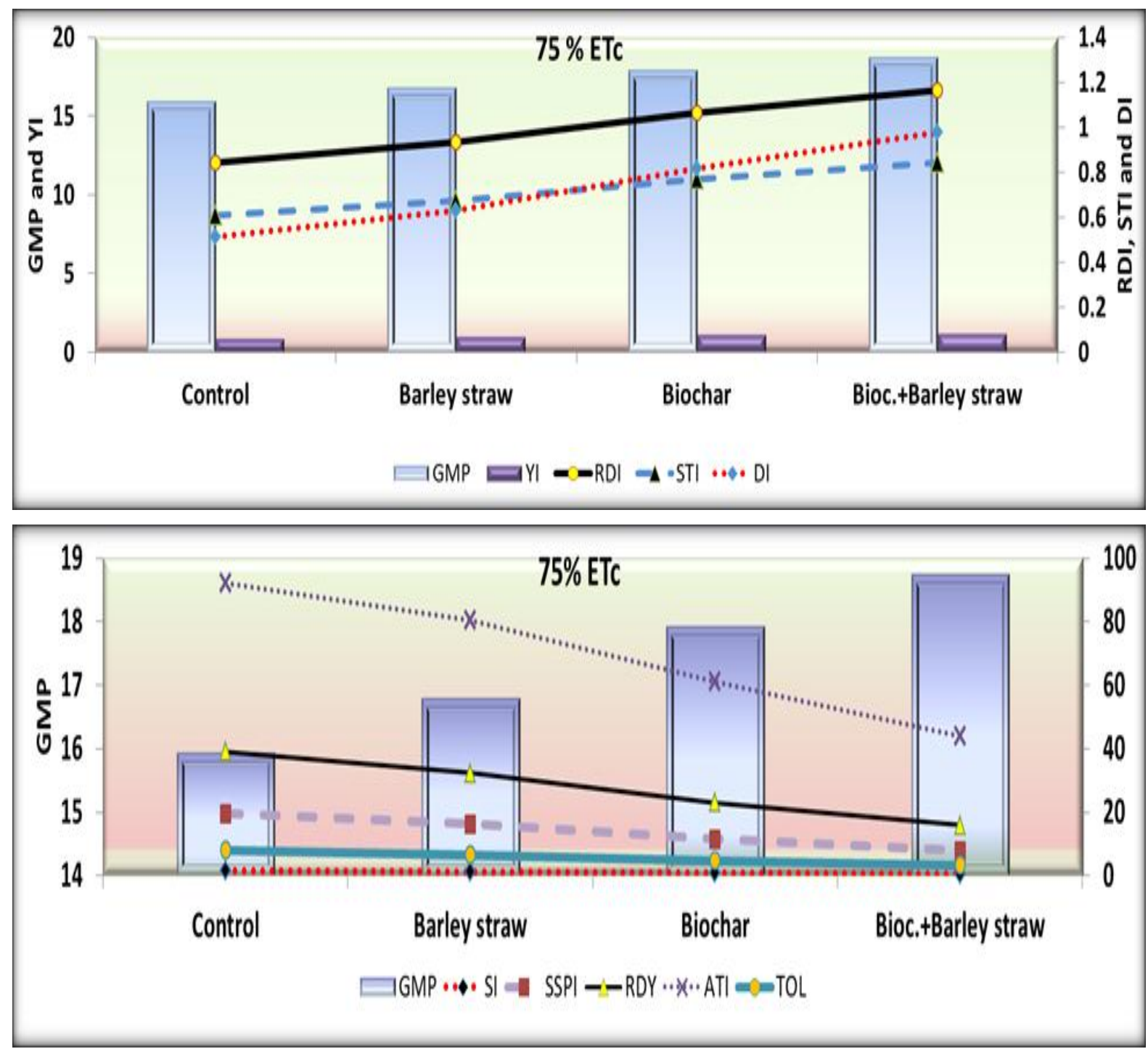

Fig. 10. Drought tolerance indices of yield under non-stress and $75 \%$ ETc stress conditions (average of both seasons) 


\section{Cluster Analysis}

Construction of dendrogram based on 12 drought tolerance indices, leaf area, average fruit weight and fruit yield (ton/fed) under non-stress, $\mathrm{D}_{\mathrm{H}}(55 \% \mathrm{ETc})$ and $\mathrm{D}_{\mathrm{M}}(75 \%$ ETc) drought conditions was illustrated in Fig. 11. As for fruit yield (ton/fed) under non-stress and $\mathrm{D}_{\mathrm{H}}$ drought $(55 \% \mathrm{ETc})$ conditions, the 4-amendment treatments splited into two main clusters (Fig. 11, down). Cluster I contained stress tolerant treatments that had low value of stress susceptibility (ATI, TOL, SI and SSPI as well as RDY $>25<50$ ) and high value of GMP, DI, $\mathrm{MK}_{1}, \mathrm{MK}_{2}, \mathrm{YI}$, RDI and STI tolerance indices (Biochar and Biochar + ST) in which the yield of amended drought treatments (13.36 and 13.91 ton/fed) exceeded corresponding control of stress one (10.455 ton/fed) by 27.8 and 33\%, respectively (Figs. 6 and 11), where the GS12 genotype in cluster I had a moderate performance in both environments than any other treatments tested in this study. Moreover, both amendment treatments exhibited moderate yield (under the two conditions) and dependable drought tolerance indices such as STI, GMP, YI, DI and MP. Therefore, this group was considered as the most desirable cluster for both growth conditions. This implies that selecting for those indices will provide preference of the plant with those amendment treatments in this cluster over others (Ene et al., 2016). However, this classification was in accordance with the results of Farshadfar $\boldsymbol{e t}$ al., (2012) as well as Eid and Sabry, 2019). Cluster II in the reverse trend of tolerant-group contained both ST and the control as highly sensitive treatment. These treatments were characterized by low-yield performance and moderate for both leaf area and average fruit weight under non-stress conditions. Both amendments clustered in cluster II had high values of SSPI, ATI, SI and TOL low values of STI and GMP. Therefore, they were identified as high-sensitive treatments to moisture stress with least stability performance. Hence, plants clustered in this group performed poorly under both growth conditions. However, this classification was in paralleled with the results of Farshadfar et al. (2012). As for $75 \%$ ETc moderate drought stress $\left(\mathrm{D}_{\mathrm{M}}\right)$, construction of dendrogram based on abovementioned 12 drought tolerance indices and yield under non-stress and 75\% ETc drought conditions $\left(D_{M}\right)$ was illustrated in Table 7 and Figs. 10 and 11 (Right).

The four amendment treatments split into three main clusters. Cluster I contained high tolerant amendment treatments that had low value of stress susceptibility (TOL, SSPI, RDY $(<25)$, ATI and SI) and high value of DI, YI and STI, $\mathrm{K}_{1}$ STI, $\mathrm{K}_{2} \mathrm{STI}$, GMP and tolerance indices (Fig. 11), i.e., Biochar+ barly straw treatment (improved from $\mathrm{T}$ under $\mathrm{D}_{\mathrm{H}}$ to $\mathrm{HT}$ under $\mathrm{D}_{\mathrm{M}}$ ). The amendment treatments in this cluster exhibited a higher performance in both environments than any other treatment tested in this study.

Moreover, these treatments had high yield under both conditions as well as dependable drought tolerance indices such as GMP, STI, YI and DI. Therefore, this group was considered as the most desirable cluster for both growth conditions. This implies that selecting for those indices will provide preference of the biochar plus barley straw amendment treatment in this cluster over others (Ene et al., 2016). However, this classification was in accordance with the results of Farshadfar 
et al. (2012) as well as Eid and Sabry (2019). Cluster II contained tolerant (Biochar) treatment that had high value of tolerance indices (DI, YI, STI and RDY <25), while cluster III include both barley straw (ST) and control treatments those had high values of stress susceptibility (ATI, TOL, SSPI and RDY > 25<50). Treatment with biochar alone had median values of yield under both moisture regimes $(100 \%$ and $75 \%$ ETc). Only two treatments made the cluster III, including the highly sensitive effect of drought, with the lowest performance in terms of stability. Hence, plants grouped in this cluster gave low yield under both growing conditions. Cluster analysis has been used in many studies to classify treatments according to their plants' response to drought. Several authors such as Farshadfar et al. (2013) and Mursalova et al. (2015) concluded that cluster analysis based on indicators of drought tolerance and yield under drought stress and nonstress conditions is appropriate for selecting drought-tolerant crops.

Table 7. Drought tolerance indices for leaf $\operatorname{area}\left(\mathrm{m}^{2}\right)$, average fruit weight $(\mathrm{g})$ and total fruit yield (ton/fed.) under moderate drought, $D_{M}(75 \%$ ETc) stress conditions (average of both seasons)

\begin{tabular}{|c|c|c|c|c|c|c|c|c|c|c|c|c|}
\hline Item & RDI & STI & $\overline{\text { GMP }}$ & TOL & YI & DI & SSPI & RDY & ATI & $\mathrm{K}_{1} \mathrm{STI}$ & $\mathrm{K}_{2} \mathrm{STI}$ & SI \\
\hline \multicolumn{13}{|c|}{ Leaf area $\left(\mathrm{m}^{2}\right)$} \\
\hline Control & 0.87 & 0.51 & 1.48 & 1.02 & 0.87 & 0.44 & 24.52 & 49.03 & 0.88 & 0.51 & 0.39 & 1.18 \\
\hline ST & 0.99 & 0.58 & 1.57 & 0.88 & 0.99 & 0.57 & 21.14 & 42.27 & 0.81 & 0.58 & 0.56 & 1.02 \\
\hline ВCH & 1.01 & 0.59 & 1.59 & 0.85 & 1.01 & 0.59 & 20.53 & 41.06 & 0.79 & 0.59 & 0.60 & 0.99 \\
\hline $\mathrm{BCH}+\mathrm{ST}$ & 1.14 & 0.66 & 1.69 & 0.70 & 1.14 & 0.75 & 16.79 & 33.57 & 0.69 & 0.66 & 0.86 & 0.81 \\
\hline \multicolumn{13}{|c|}{ Average fruit weight (g) } \\
\hline Control & 0.93 & 0.85 & 82.00 & 13.11 & 0.93 & 0.79 & 7.38 & 14.76 & 986.57 & 0.85 & 0.73 & 1.80 \\
\hline ST & 1.02 & 0.93 & 85.80 & 5.93 & 1.02 & 0.95 & 3.34 & 6.67 & 466.72 & 0.93 & 0.96 & 0.81 \\
\hline $\mathbf{B C H}$ & 1.02 & 0.93 & 85.84 & 5.85 & 1.02 & 0.95 & 3.30 & 6.59 & 461.40 & 0.93 & 0.97 & 0.80 \\
\hline BCH+ST & 1.04 & 0.95 & 86.68 & 4.22 & 1.04 & 0.99 & 2.38 & 4.76 & 336.20 & 0.95 & 1.03 & 0.58 \\
\hline \multicolumn{13}{|c|}{ Total fruit yield (ton/fed.) } \\
\hline Control & 0.84 & 0.61 & 15.94 & 7.99 & 0.84 & 0.51 & 19.55 & 39.11 & 92.21 & 0.61 & 0.43 & 1.42 \\
\hline ST & 0.93 & 0.68 & 16.79 & 6.63 & 0.93 & 0.63 & 16.23 & 32.45 & 80.59 & 0.68 & 0.59 & 1.18 \\
\hline $\mathbf{B C H}$ & 1.06 & 0.77 & 17.92 & 4.71 & 1.06 & 0.82 & 11.51 & 23.03 & 61.05 & 0.77 & 0.87 & 0.83 \\
\hline $\mathbf{B C H}+\mathrm{ST}$ & 1.16 & 0.84 & 18.74 & 3.24 & 1.16 & 0.98 & 7.92 & 15.83 & 43.89 & 0.84 & 1.14 & 0.57 \\
\hline
\end{tabular}



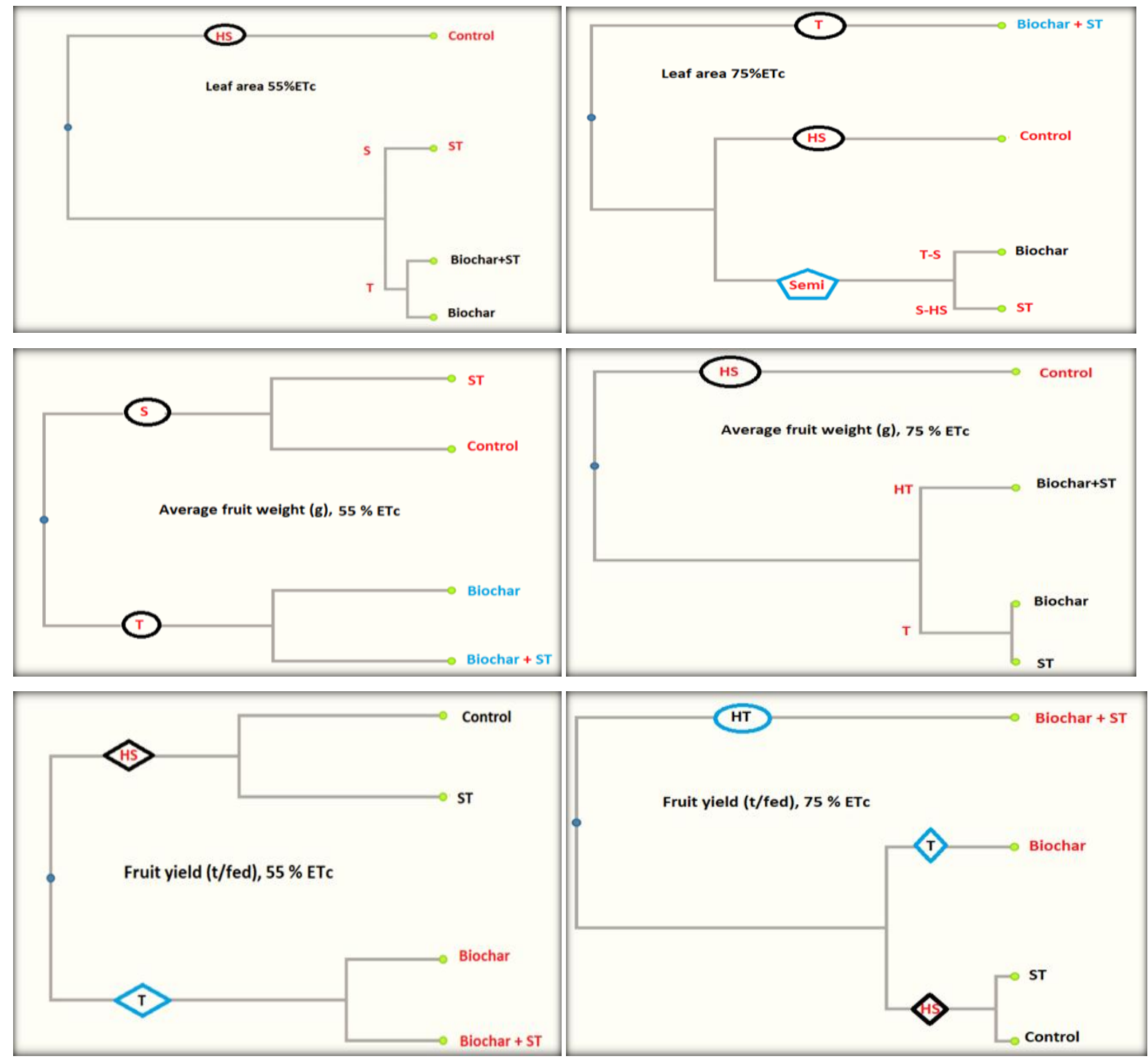

$\mathbf{D}_{\mathbf{H}}$

$\mathbf{D}_{\mathbf{M}}$

Fig. 11. Dendrogram of four amendment treatments based on cluster analysis showing classification based on leaf area, average fruit weight and total fruit yield as well as both $55 \%\left(D_{H}\right)$ and $75 \%\left(D_{M}\right)$ ETc drought tolerance indices

\section{REFERENCES}

Abdelghany, A.H.; Abouzied, H.M. and Badran, M.S. (2016). Evaluation of some Egyptian wheat cultivars under water stress condition in the North Western coast of Egypt. J. Agric. and Env. Sci., 15 (1): 63-84.

Agbna, G.H.D.; Dongli, S.; Zhipeng, L.; Elshaikh, N.A.; Guangcheng, S. and Timm, L.C. (2017). Effects of deficit irrigation and biochar addition on the growth, yield, and quality of tomato. Scientia Hort., 222:90-101

Ahmad, A.; Wu, Y.Y.; Xing, D.K.; Qaiser, J. and Ikram, U. (2017). Photosynthetic response of two okra cultivars under salt stress and rewatering. J. Plant Interactions, $12: 67$ -77 .

Akhtar, K.; Wang, W.; Ren, G.; Khan, A.; Feng, Y. and Yang, G. (2018). Changes in soil enzymes, soil properties 
and maize crop productivity under wheat straw mulching in Guanzhong. China. Soil Til. Res., 182: 94-102

Ali, S.; Rizwan, M.; Qayyum, M.F.; Ok, Y.S.; Ibrahim, M.; Riaz, M.; Arif, M.S.; Hafeez, F.; Al-Wabel, M.I. and Shahzad A.N. (2017). Biochar soil amendment on alleviation of drought and salt stress in plants: a critical review. Environ. Sci. Pollut. Res., 24 : 12700-12712

AOAC (1990). Official Methods of Analysis of the Association of Official Analytical Chemist. $15^{\text {th }}$ Ed., Washington, USA.

Atkin, R.K.; Barton, G.E. and Robinson, D.K. (1973). Effect of root growing temperature on growth substances in xylem oxudates of Zea mays. J. Exp. Bot., 24: 475-487.

Blum, A. (1997). Crop Responses to Drought and the Interpretation of Adaptation. In: Belhassen I (ed.) Drought Tolerance in Higher Plants: Genetical, Physiological, and Molecular Biological Analysis. Kluwer Academic Publ. Dordrecht, 57-70.

Chakraborty, D.; Nagarajan, S.; Aggarwal, P.; Gupta, V.K.; Tomar, R.K.; Garg, R.N.; Sahoo, R.N.; Sarkar, A.; Chopra, U.K.; Sarma, K.S.S. and Kalra, N. (2008). Effect of mulching on soil and plant water status, and the growth and yield of wheat (Triticum aestivum L.) in a semi-arid environment. Agric. Water Mgt., 95: 1323-1334.

Chirak, E.L.; Orlova, O.V.; Aksenova, T.S.; Kichko, A.A.; Chirak, E.R., Provorov, N.A. and Andronov, E.E. (2017). Dynamics of chernozem microbial community during biodegradation of cellulose and barley straw. Agric. Biol., 52: 588-596.
Costa, M.; Maria, F.O. and Chaves, M.M. (2007). Deficit irrigation as a strategy to save water: physiology and potential application to horticulture. J. Integrative Plant Biol., 49 (10): 14211434.

Duncan, D.B. (1955). Multiple Ranges and Multiple F. test. Biometrics, П: 142 .

Eid, M.H. and Sabry, S. (2019). Assessment of variability for drought tolerance indices in some wheat (Triticum aestivum L.) genotypes. Egypt. J. Agron., 41 (2): 79-91.

Elad, Y.; David, D.R.; Harel, Y.M.; Borenshtein, M.; Kalifa, H.B. Silber, A. and Graber, E.R. (2010). Induction of systemic resistance in plants by biochar, a soil-applied carbon sequestering agent. Phytopathol., 100: 913-921.

Ene, O.; Peter, E. and Christian, U. (2016). Studies of phenotypic and genotypic variation in sixteen cucumber genotypes. Chil. J. Agric. Res., 76 (13): 307-311.

Farshadfar, E. and Sutka, J. (2002). Screening drought tolerance criteria in maize. Acta Agron Hung. Acta. Agron. Hung, 50 (4): 411-416.

Farshadfar, E.; Elyasi, P. and Aghaee, M. (2012). In vitro selection for drought tolerance in common wheat (Triticum aestivum L.) genotypes by mature embryo culture. Ame. J. Sci. Res., 48: 102-115.

Farshadfar, E.; Poursiahbidi, M.M. and Safavi, S.M. (2013). Assessment of drought tolerance in land races of bread wheat based on resistance/tolerance indices. Int. J. Adv. Biol. Biomed. Res., 1: 143-158.

Fernandez, G.C.J. (1992). Effective selection criteria for assessing stress tolerance. In: Kuo C.G. (Ed.), Proc. Int. Symposium on Adaptation of 
Vegetables and Other Food Crops in Temperature and Water Stress, Aug. 1316, Shanhua, Taiwan., 257-270.

Fischer, R.A. and Maurer, R. (1978). Drought resistance in spring wheat cultivars. I. Grain yield responses. Aust. J. Agric. Res., 29: 897-912.

Fischer, R.A. and Wood, T. (1979). Drought resistance in spring wheat cultivars. III. Yield association with morphological traits. Aust. J. Agric. Res., 30: 1001-1020.

Foti, S.; Mauromicale, G. and Ierna, A. (1995). Influence of irrigation regimes on growth and yield of potato $c v$. Spunta. Potato Res., (38): 307-318.

Gavuzzi, P.; Rizza, F.; Palumbo, M.; Campaline, R.G.; Ricciardi, G.L. and Borghi, B. (1997). Evaluation of field and laboratory predictors of drought and heat tolerance in winter cereals. Plant Sci., 77: 523-531.

Hafez, Y.; Attia, K.; Alamery, S.; Ghazy, A.; Al-Doss, A.; Ibrahim, E.; Rashwan, E.; El-Maghraby, L.; Awad, A. and Abdelaal, K. (2020). Beneficial effects of biochar and chitosan on antioxidative capacity, osmolytes accumulation, and anatomical characters of water-stressed barley plants. Agron., 10: 630.

Hsiao, T.C.; Acevedo, E.; Fereres, E. and Henderson, D.W. (1974). Water Stress, Growth, and Osmotic Adjustment. Phil. Trans. R. Soc. Lon. B., 273 (927): 479-500. http://www.jstor.org/stable/ 2417545.

Hussain, M.; Malik, M.A.; Farooq, M.; Ashraf, M.Y. and Cheema, M.A. (2008). Improving drought tolerance by exogenous application of glycinebetaine and salicylic acid in sunflower. J. Agron. Crop Sci., 194: 193-199.

Jones, J.B.; Wolf, B. and Mills, H.A. (1991). Plant Analysis Handbook: A Practical Sampling, Preparation,
Analysis, and Interpretation Guide. (Micro-Macro Publishing Inc., 1991).

Kovach, W.T. (1995). Multivariate Statistics Package for IBMPc and Compatibles, Kovach, Computing Service, 85 Nart. Y Delin, Pentreaeth, Anglesely LL 758 UY Wales, U.K.

Lan, J. (1998). Comparison of evaluating methods for agronomic drought resistance in crops. Acta Agric Borealioccidentalis Sinica., 7: 85-87.

Langeroodi, A.R.S.; Campiglia, E.; Mancinelli, R. and Radicetti, E. (2019). Can biochar improve pumpkin productivity and its physiological characteristics under reduced irrigation regimes? Sci. Hortic., 247, 195-204.

Lehmann, J. and Joseph, S. (2015). Biochar for environmental management: An introduction. In Biochar for Environ. Manag. Sci., Technol. and Implement. Published by Routledge, 976.

Li, L.; Zhang, Y.J.; Novak, A.; Yang, Y. and Wang, J. (2021). Role of Biochar in Improving Sandy Soil Water Retention and Resilience to Drought. Water, 13 (4), 407.

Marker, A.F.H. and Jinks, S. (1982). The spectrophotometric analysis of chlorophyll a and phaeopigments in acetone, ethanol and methanol. Arch. Hydrobiol. Beih. Ergebn. Limnol., 16: 3-17.

Marschner, H. (1995). Mineral Nutrition of Higher Plants. $2^{\text {nd }}$ Ed. Academic Press, London, U.K.

Mary, G.S.; Sugumaran, P.; Niveditha, S.; Ramalakshmi, B.; Ravichandran, P. and Seshadri, S. (2016). Production, characterization and evaluation of biochar from pod (Pisum sativum), leaf (Brassica oleracea) and peel (Citrus sinensis) wastes. Int. J. Recycl. Org. Waste Agric., 5: 43-53 
Moghaddam, A. and Hadizadeh, M.H. (2002). Response of corn hybrids and their parental lines to drought using different stress tolerant indices. Seed Plant Improv. J., 18(3): 255-272.

Moosavi, S.S.; Yazdi Samadi, B.; Naghavi, M.R.; Zali, A.A.; Dashti, H. and Pourshahbazi, A. (2008). Introduction of new indices to identify relative drought tolerance and resistance in wheat genotypes. Desert (BIABAN), 12: $165-178$

Mukome, F.N.D.; Zhang, X.; Silva, L.C.R.; Six, J. and Parikh, S.J. (2013). Use of chemical and physical characteristics to investigate trends in biochar feedstocks. J. Agric. Food Chem., 61(9): 2196-2204.

Mursalova, J.; Akparov, Z.; Ojaghi, J.; Eldarov, M.; Belen, S.; Gummadov, N. and Morgounov, A. (2015). Evaluation of drought tolerance of winter bread wheat genotypes under drip irrigation and rain-fed conditions. Turk. J. Agric. For., 39: 1-8.

Obreza, T.A.; Pitts, D.J.; Govern, R.J. and Spreen, T.H. (1996). Deficit irrigation of micro-irrigated tomato affects yield, fruit quality, and disease severity. J. Prod. Agric., 9: 270-275.

Pan, J.L.; Dai, W.A.; Shang, Z.H. and Guo, R.Y. (2013). Review of research progress on the influence and mechanism of field straw residue incorporation on soil organic matter and nitrogen availability. Chinese J. EcoAgric., 21: 526-535.

Petersen, C.T.; Hansen, E.; Larsen, H.H.; Hansen, L.V.; Ahrenfeldt, J. and Hauggaard-Nielsen, H. (2016). Pore-size distribution and compressibility of coarse sandy subsoil with added biochar. Eur. J. Soil Sci., 67: 726-736.

Qayyum, M.F.; Abid, M.; Danish, S.; Saeed, M.K. and Ali, M.A. (2015).
Effects of various biochars on seed germination and carbon mineralization in an alkaline soil. Pak. J. Agric. Sci., 51: 977-982.

Rosielle, A.A. and Hamblin, J. (1981). Theoretical aspects of selection for yield in stress and non-stress environments. Crop Sci., 21: 943-946

She, D.; Sun, X.; Gamareldawla, A.H.D.; Nazar, E.A., Hu, W.; Edith, K. and Yu, S. (2018). Benefits of soil biochar amendments to tomato growth under saline water irrigation. Scien. Reports, 8: 14743.

Shirazi, M.; Naroui, R.M.; Kazemi, H. and Alizadeh, B. (2009). Evaluation of moisture deficit on seven grain sorghums by drought stress indices. Pajouhesh and Sazandegi, 160-164.

Singh, M.; Saini, R.K. and Singh, S. (2019). Potential of integrating biochar and deficit irrigation strategies for sustaining vegetable production in water-limited regions: A Rev. Hort. Sci., 54 (11): 1872-1878.

Smith, P.G. and Dale, J.E. (1988). The effect of root cooling and excision treatments on the growth of primary leaves of Phaseolus Vulgars, L. Rapid and reversible increases in abscisic acid content. New Phytal., 110: 293-300.

Snedecor, G.W. and Cochran, W.G. (1980). Statistical Methods. $7^{\text {th }}$ Ed. Ames, Iowa USA: Iowa State Univ. Press, 507.

Suthar, R.G.; Wang, C.; Nunes, M.C.N.; Chen, J.; Sargent, S.A.; Bucklin, R.A. and Gao, B. (2018). Bamboo biochar pyrolyzed at low temperature improves tomato plant growth and fruit quality. Agric., 8: 153.

Watanabe, T.; Man, L.H.; Vien, D.M.; Khang, V.T.; Ha, N.N.; Linh, T.B. and Ito, O. (2009). Effects of continuous rice straw compost 
application on rice yield and soil properties in the Mekong Delta. Soil Sci. Plant Nutr., 55 (6): 754-763.

Wei, W.; Yang, H.; Fan, M.; Chen, H.; Guo, D.; Cao, J. and Kuzyakov, Y. (2020). Biochar effects on crop yields and nitrogen loss depending on fertilization. Sci. Total Environ., 702 ; 134423.

Wyszkowska, J.; Tomkiel, M.; Borowik, A.; Baćmaga, M. and Kucharski, J. (2021). Effect of Bentonite and Barley Straw on the Restoration of the Biological Quality of Agriculture Soil Contaminated with the Herbicide Successor T 550 SE. Agric., 11(1): 27.
Yang, S.; Wang, Y.; Liu, R.; Li, Q. and Yang, Z. (2018). Effects of straw application on nitrate leaching in fields in the Yellow River irrigation zone of Ningxia, China. Sci. Rep., 8: 954.

Younis, U.; Qayyum, M.F.; Shah, M.H.R.; Danish, S.; Shahzad, A.N.; Malik, S.A. and Mahmood, S. (2015). Growth, survival, and heavy metal (cd and ni) uptake of spinach (Spinacia oleracea) and fenugreek (Trigonella corniculata) in a biochar-amended sewage-irrigated contaminated soil. J. Plant Nutr. Soil Sci., 178: 209-217. 


\author{
الملخص العربي \\ استجابة نباتات الطماطم تحت الإجهاد المائي لمحسنات التربة العضوية \\ محمود إبراهيم محمود1، سـامح عبدالحفيظ علي أبو القاسم²، محمد سعد عبدالحميد القصاص3 3 \\ 1. قسم الانتاج النباتي (فرع الخضر)، كلية العلوم الزراعية البيئية، جامعة العريش، مصر. \\ 2. قسم بحوث الخضر ذاتية التلقيح، معهد بحوث البساتين، مركز البحوث الزر اعية بالجيزة، مصر. \\ 3. قسم الأراضي والمياه، كلية العلوم الزراعية البيئية، جامعة العريش، مصر.
}

أجريت تجربتان حقليتان خلال موسمين صيفيين متتالبين لعامي 2019 و و2020 بالمزر عة البحنية لكلية العلوم الزر اعية البيئية، جامعة العريش، شمال سيناء لدراسة تأثثر إجهاد الجفاف (100\% و و\%5\% و75\% و55\% من من

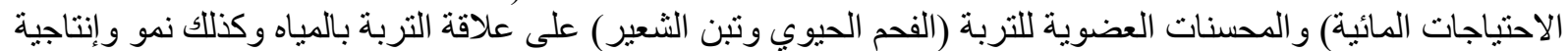

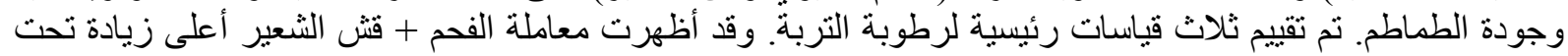

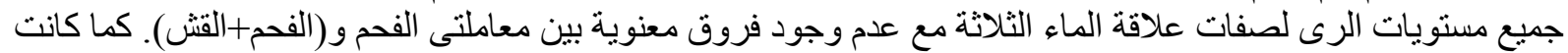

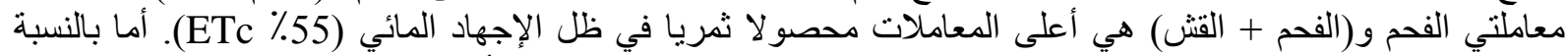

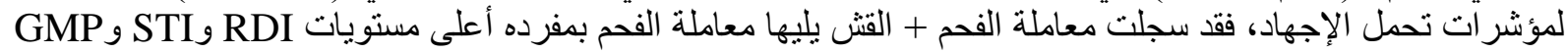

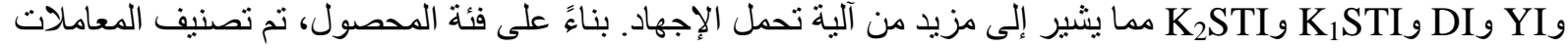

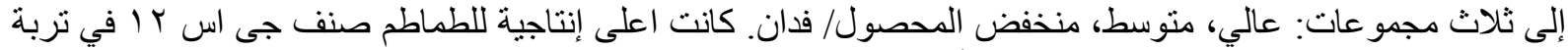
طينية رملية تحت الري بنسبة 75٪ من ETc أعطت زيادة في المحصول مقارنة مع إنتاجيتهم تحت إجهاد الجفاف بنسبة

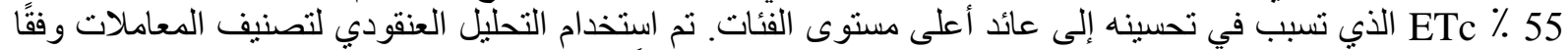

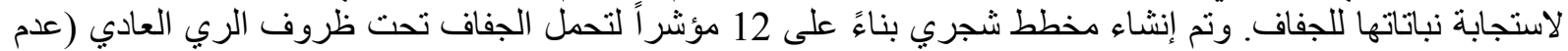
الإجهاد) وظروف الجفاف المرتفعة (5Tc \% ETc) و المتوسطة (ETc \% (ET) وقد أكد التحليل العنقودي مدى مطابقة النتائج

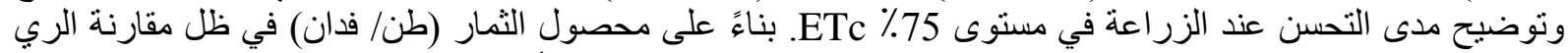

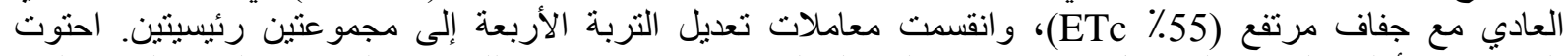

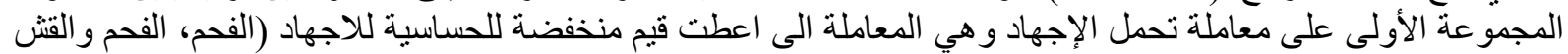

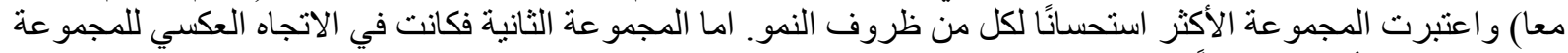

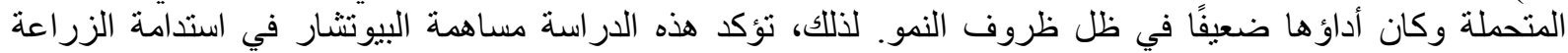
و الحفاظ على المياه. الكلمات الاسترشـادية: طماطم، الاجهاد المائي، الفحم الحيوى، قش الشعير.

أستاذ الخضر ، كلية العلوم الزر اعية البيئية، جامعة العريش، مصر. أستاذ الخضر، معهذ بحوث البساتين، مركز البحوث الزر اعية، مصر.

\section{المحكمــــــــ}

1- أ.د. علي إبراهيم القصاص: أدماء

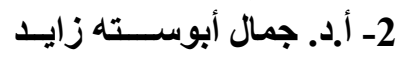

